Review

\title{
Analyzing Barriers of Circular Food Supply Chains and Proposing Industry 4.0 Solutions
}

\author{
Nesrin Ada ${ }^{1}$, Yigit Kazancoglu ${ }^{2}$, Muruvvet Deniz Sezer ${ }^{3, * \mathbb{D}}$, Cigdem Ede-Senturk $^{3}$, Idil Ozer ${ }^{3}$ \\ and Mangey Ram ${ }^{4,5}$
}

check for updates

Citation: Ada, N.; Kazancoglu, Y.; Sezer, M.D.; Ede-Senturk, C.; Ozer, I.; Ram, M. Analyzing Barriers of Circular Food Supply Chains and Proposing Industry 4.0 Solutions. Sustainability 2021, 13, 6812. https://doi.org/10.3390/su13126812

Academic Editors: Guo Li, Sachin Mangla, Jiasen Sun, Huamin $\mathrm{Wu}$, Xiaohang Yue and Riccardo Testa

Received: 19 February 2021

Accepted: 12 June 2021

Published: 16 June 2021

Publisher's Note: MDPI stays neutral with regard to jurisdictional claims in published maps and institutional affiliations.

Copyright: (c) 2021 by the authors. Licensee MDPI, Basel, Switzerland. This article is an open access article distributed under the terms and conditions of the Creative Commons Attribution (CC BY) license (https:/ / creativecommons.org/licenses/by/ $4.0 /)$.
1 Department of Business Administration, Ege University, Izmir 35100, Turkey; nesrin.ada@ege.edu.tr

Department of Logistics Management, Yasar University, Izmir 35100, Turkey; yigit.kazancoglu@yasar.edu.tr

3 Department of Business Administration, Yasar University, Izmir 35100, Turkey; edecigdem@gmail.com (C.E.-S.); idilozer83@gmail.com (I.O.)

4 Department of Mathematics, Computer Science and Engineering, Graphic Era Deemed to be University, Dehradun 248002, India; mangeyram@geu.ac.in

5 Institute of Advanced Manufacturing Technologies, Peter the Great St. Petersburg Polytechnic University, 195251 Saint Petersburg, Russia

* Correspondence: deniz.sezer@yasar.edu.tr; Tel.: +90-(232)-570-8978

\begin{abstract}
The concept of the circular economy (CE) has gained importance worldwide recently since it offers a wider perspective in terms of promoting sustainable production and consumption with limited resources. However, few studies have investigated the barriers to CE in circular food supply chains. Accordingly, this paper presents a systematic literature review of 136 papers from 2010 to 2020 from WOS and Scopus databases regarding these barriers to understand CE implementation in food supply chains. The barriers are classified under seven categories: "cultural", "business and business finance", "regulatory and governmental", "technological", "managerial", "supply-chain management", "knowledge and skills". The findings show the need to identify barriers preventing the transition to $\mathrm{CE}$. The findings also indicate that these challenges to $\mathrm{CE}$ can be overcome through Industry 4.0, which includes a variety of technologies, such as the Internet of Things (IoT), cloud technologies, machine learning, and blockchain. Specifically, machine learning can offer support by making workflows more efficient through the forecasting and analytical capabilities of food supply chains. Blockchain and big data analytics can provide the necessary support to establish legal systems and improve environmental regulations since transparency is a crucial issue for taxation and incentives systems. Thus, CE can be promoted via adequate laws, policies, and innovative technologies.
\end{abstract}

Keywords: circular economy; food supply chain; industry 4.0; sustainability

\section{Introduction}

According to the UN's Food and Agriculture Organization, one third of food produced is lost or wasted every year [1]. The report also notes differences between low- and medium-, and high-income countries in terms of the losses at various stages of supply chains. In low- and medium-income countries, food loss mostly occurs at the beginning of the production and supply chains whereas food in high-income countries is thrown away by retailers or consumers to become food waste at the consumption stage [1]. Additionally, the reasons for food losses and waste vary by countries' income level. In low-income countries, the causes are mostly related to financial restrictions and lack of technical knowledge in harvesting techniques and infrastructure whereas in medium or high-income countries the causes are connected to consumer behaviors and lack of coordination among stakeholders in the food supply chain.

Overall, increasing food waste is becoming a global issue regarding food security, which requires simultaneous management of environmental, economic, and social impacts. 
In order to eliminate these impacts, it is crucial to create a more sustainable food supply chain. Therefore, the concept of the $\mathrm{CE}$ has recently emerged as a response to the current linearity of the food supply chain. It offers an alternative method to the unsustainable linear economic model, which is identified with the 'take, make, and dispose' trilogy [2]. Moreover, increasing urbanization poses new challenges globally. More than half of the world's population already live in urban areas, and this proportion is anticipated to rise to $80 \%$ by 2050 [3]. Meanwhile, the tremendously increasing world population increases demand for resources in urban regions as well as causing environmental problems, socioeconomic inequalities, and new energy needs [4].

As a sustainable economic method, CE reduces the extraction of raw materials and enables recirculation of resources, thereby creating advantageous environments for both societies and industries. [5]. Among the many aims of CE, the most important is keeping materials available to decrease waste and energy use instead of disposing of them [6]. However, implementing CE requires both radical alternative economic solutions and novel management of resources [7]. CE mainly aims to resolve problems of resource use, waste, and emissions throughout the supply chain. These goals can be achieved by offering products, components, and materials with the minimum possible waste or even zero waste [8-10].

The transition from a linear economy to CE has created many requirements, such as increasing product reliability and quality [11]. Due to increased forward and reverse activities in the supply chain, businesses also need to adapt themselves to manage these dynamic characteristics and deal with multiple stakeholders and unpredictable conditions. To achieve CE, it is necessary to deal with various obstacles, such as strict legal regulations, high technology investment, company corporate culture, and insufficient knowledge of $\mathrm{CE}$. While moving towards $\mathrm{CE}$, many business models require a fundamental change to find new sustainable solutions. Businesses must therefore understand and overcome the challenges and barriers of $C E$ to ensure sustainable development.

Despite its importance, few studies have integrated CE philosophy into the food supply chain $[12,13]$. It is also necessary to analyze the challenges during the transition to CE. While some studies have investigated obstacles to CE implementations [14-16], few studies have considered how digital technologies can be used to tackle CE barriers. Therefore, it is important to fill this gap [17]. Accordingly, this paper systematically analyzes the barriers to implementing CE in the food supply chain. It is important to understand current challenges, as viewed by industry, academics, and policymakers, to encourage future research, support companies, and determine the necessary regulations to move towards CE. Then, the importance of digital technologies is presented in order to overcome CE barriers.

The main research objectives of this study are as follows:

- To investigate the key barriers when implementing CE dimensions in the food supply chain;

- To systematically categorize CE dimensions for the food supply chain to overcome challenges;

- $\quad$ To analyze interaction effects between CE dimensions and food supply chain stages and between $\mathrm{CE}$ dimensions and sub-sectors of the food industry;

- To determine the benefits of digital technologies to overcome CE challenges in the food supply chain.

This study contributes to the literature in three ways. First, it provides a systematic analysis of research into $C E$ barriers in food supply chains from different perspectives, such as supply chain stages, geographical context, distribution of food subsector, methods used in publications, distribution of journals, number of publications over time, CE dimensions, focused area, and interaction effects. Second, this study investigates the main barriers to implementing CE in the food supply chain. Finally, the findings of this study can help overcome challenges in circular food supply chains and highlight the importance of digital technologies to overcome CE barriers in the food supply chain. 
The remainder of the paper is organized as follows: Section 2 presents the systematic literature review methodology; Section 3 presents the results; Section 4 discusses implications and future insights; Section 5 offers the conclusions.

\section{Design of Systematic Literature Review}

This paper focuses on barriers to implementing CE in the food supply chain. It uses content analysis to investigate main and subordinate CE barriers in food supply chains from different perspectives to identify relationships and interactions among $\mathrm{CE}$ dimensions, supply chain stages, and food industry sub-sectors. It is important to identify these barriers to prevent food waste and loss and to propose digital solutions to overcome them. Thus, this study adopted a systematic literature review, which enables an in-depth understanding of any field and can provide clear conclusions for researchers. A systematic literature review follows specific procedures that are reliable, repeatable, and valid across different conditions and periods. Such an analysis aims to identify objective features [18]. The study included multiple researchers to ensure greater validity, objectivity, and reliability of the results compared to the judgments of a single researcher [19]. Content analysis must also follow a clear and predefined process, as shown in Figure 1.

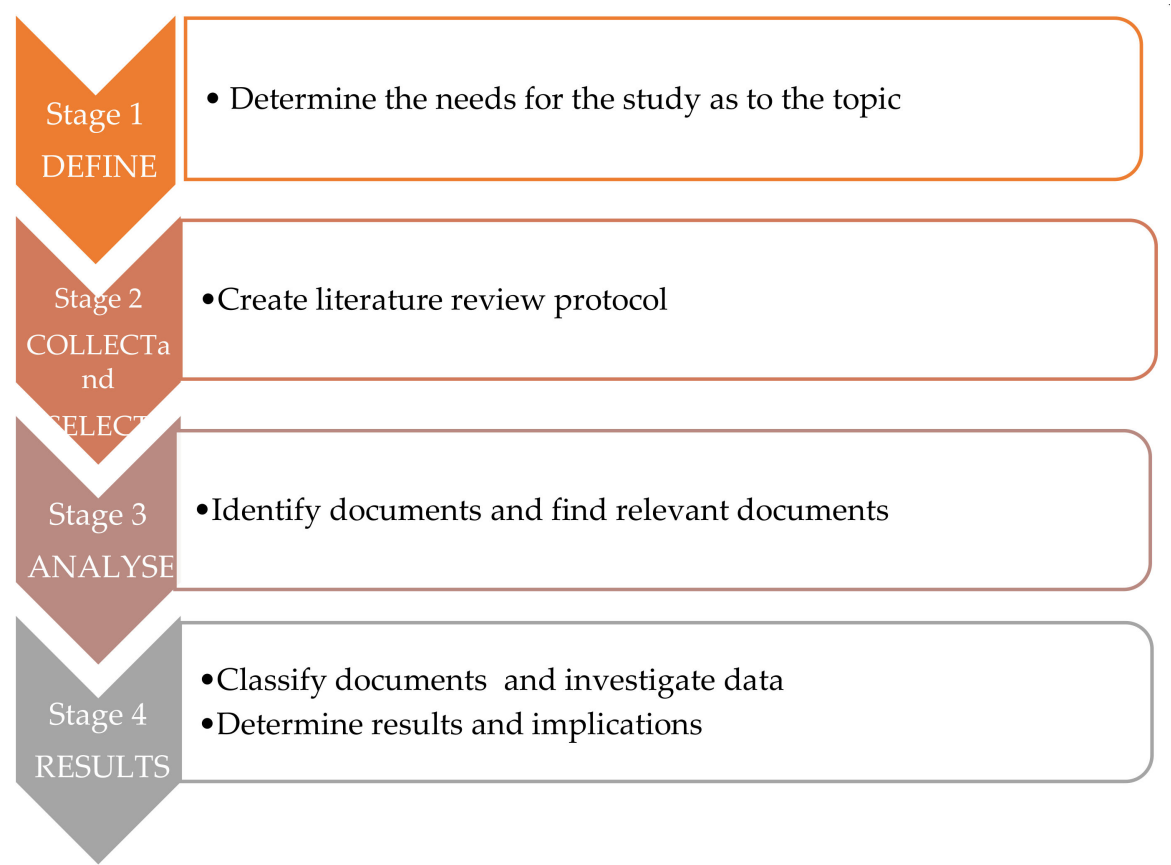

Figure 1. Systematic literature review stages.

\subsection{Selection Process}

Based on specific research strings applied to WOS and Scopus databases, 501 articles were identified initially. During the selection process, attention was focused on recent publications that successfully passed the search process to meet the research objectives. For the elimination process, keyword searches were performed to determine whether the publications met the objectives. Search strings were defined according to topics related to the search process. This step eliminated 150 articles based on the title and abstract. The remaining 201 articles were then investigated in depth in terms of their research objectives. This yielded 136 articles aligned with the research objectives of this study. The process is summarized in Figure 2. 


\begin{tabular}{|l|l|}
\hline & Articles collected based on proposed research strings \\
\hline 136 & -51 articles eliminated based on research objectives \\
\hline & - Final number of articles aligned with research objectives \\
\hline
\end{tabular}

Figure 2. Article selection process.

\subsection{Search Criteria}

The inclusion criteria for this study can be summarized as follows:

- $\quad$ Articles and conference papers, excluding books and research reports.

- Articles included in Scopus and WOS databases. Previous studies indicate that Scopus is a reputable and valuable bibliographic database for studies published after 1995. The overall coverage of the Scopus database is wider than in academic journals, and only a small percentage is not indexed in the relevant journals [5,8]. WOS and Scopus were used together to increase the reliability of the data in the present study [14].

- Articles matching the search string in Table 1 (searching in titles, abstracts, keywords).

- Articles written in English.

- Articles with open access option.

- Articles published between 2010 and 2020 to capture recent data.

Table 1. Search strings.

\begin{tabular}{|c|c|}
\hline Topics & Search String \\
\hline \multirow[t]{2}{*}{ Barriers } & $\begin{array}{l}\text { "barriers of circular economy" OR "challenges of circular } \\
\text { economy" OR "circular economy barriers" OR "circular } \\
\text { economy challenges" }\end{array}$ \\
\hline & AND \\
\hline \multirow[t]{2}{*}{ Food Supply Chain } & "food supply chain" \\
\hline & AND \\
\hline \multirow[t]{2}{*}{ Circular Economy } & $\begin{array}{l}\text { "closed-loop economy" OR "circularity" OR "application of } \\
\text { circular economy" OR "implementation of circular economy" }\end{array}$ \\
\hline & AND \\
\hline 9Rs & $\begin{array}{l}\text { "reuse" OR "reduce" OR "recycle" OR "repair" OR } \\
\text { "remanufacture" OR "repurpose" OR 'recycle' OR "recover" OR } \\
\text { "rethink". }\end{array}$ \\
\hline
\end{tabular}

The selection process is shown in Table 1.

\section{Results}

The results have two main focuses: CE barriers in the food supply chain; relationships between $\mathrm{CE}$ and digital technologies. 


\subsection{Analyses of CE Barriers in the Food Supply Chain}

The analysis was based on the distribution of years, methodology used, keywords, focused areas, CE dimensions, stage of food supply chain, sub-sectors, adoption of CE dimensions, representation of continents and regions, interaction between methods and $\mathrm{CE}$ dimensions, and interaction between $\mathrm{CE}$ dimension and research focus considering barriers of CE dimension in the food supply chain.

Regarding the distribution of journals (Figure 3), authors most commonly preferred the Journal of Cleaner Production (20\%), which mainly focuses on cleaner production, sustainability, and environmental science issues. Other high-impact journals, such as Sustainability and Waste Management, also focus on topics related to CE and sustainability.

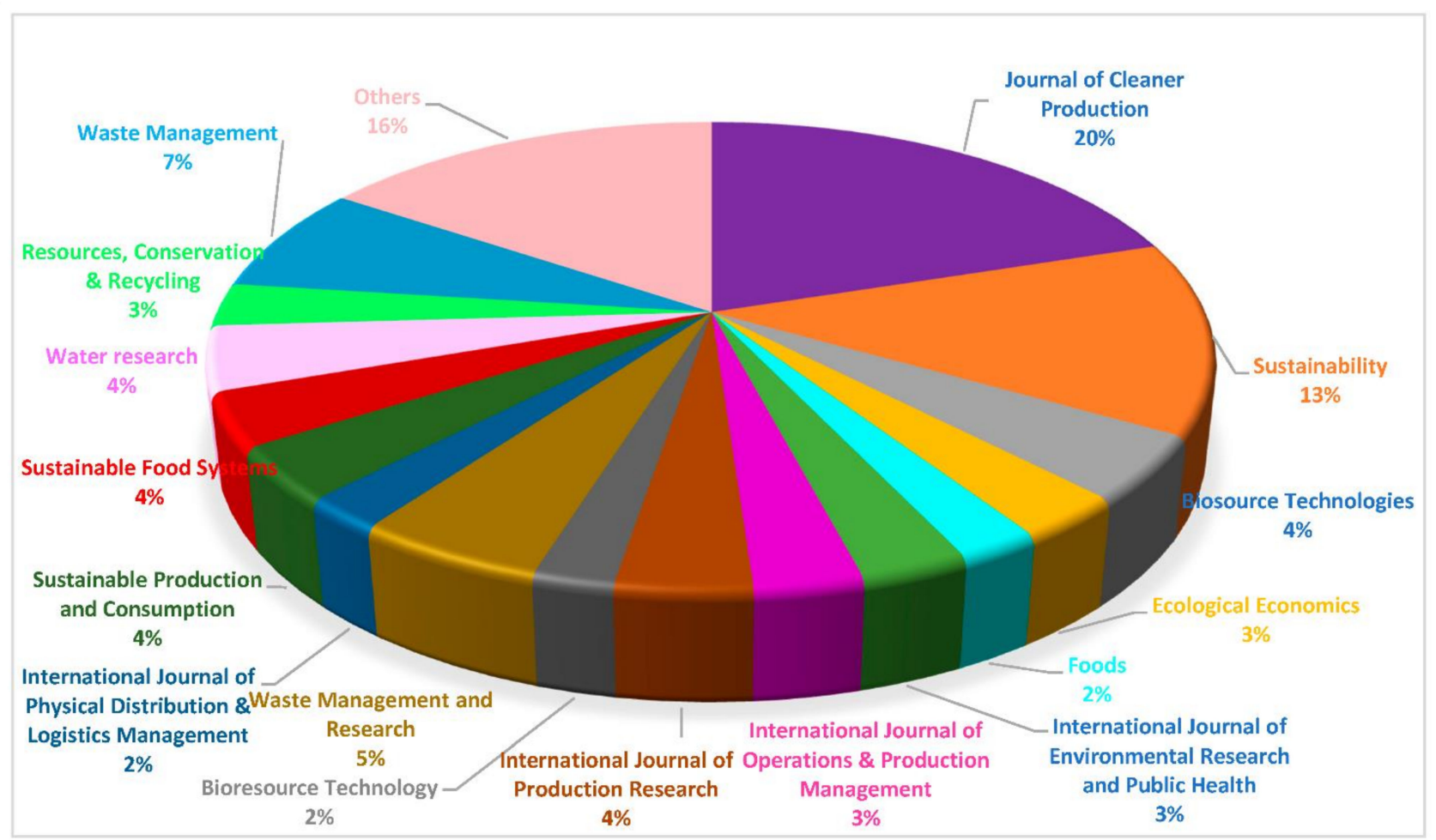

Figure 3. Distribution of journals.

Regarding the distribution of articles over time (Figure 4), CE-related articles increased rapidly between 2016 and 2019. Thus, sustainability and CE in the food supply chain has undoubtedly become a prominent issue during the last 10 years and attracted the attention of researchers, especially regarding CE-related barriers and practices in food supply chains. 


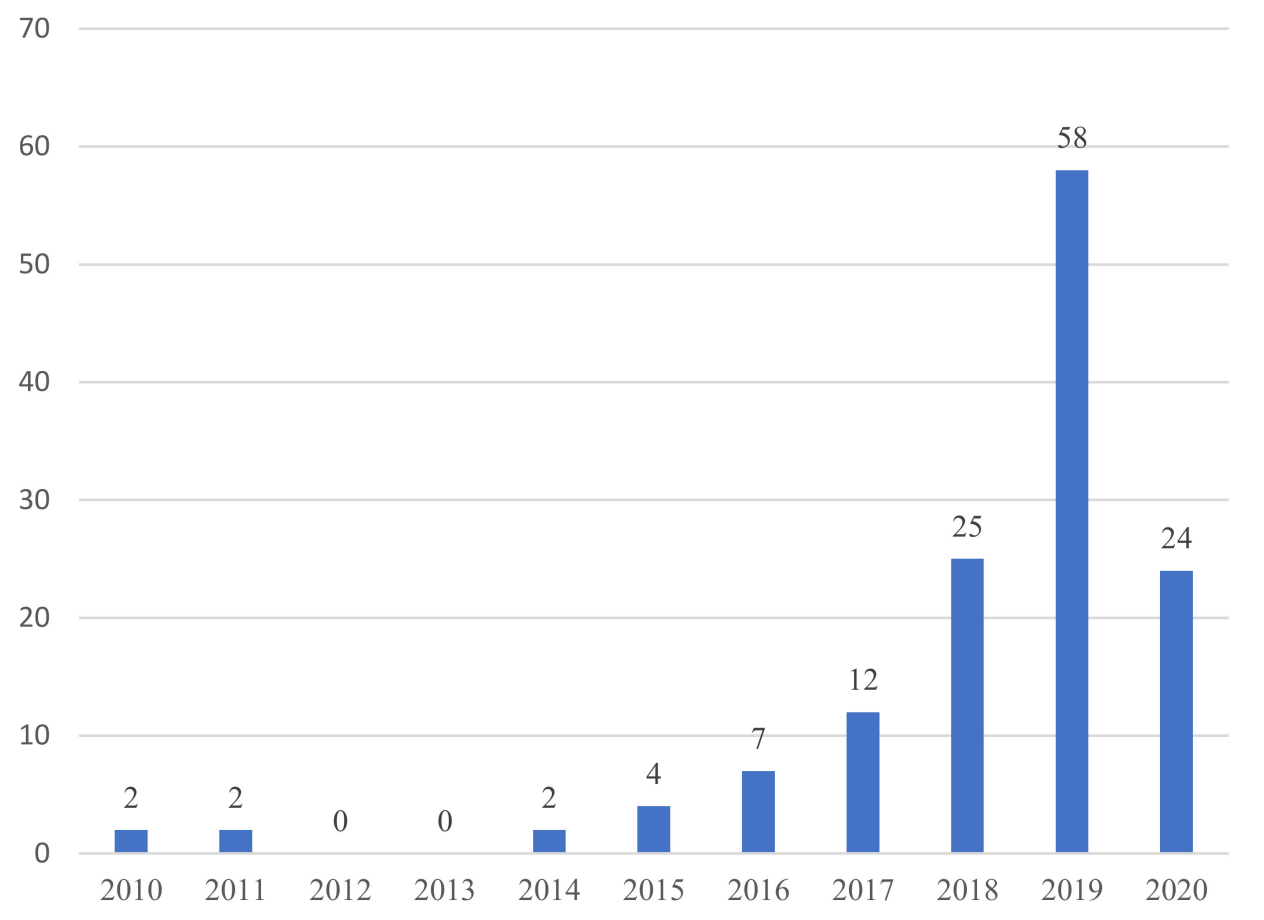

Figure 4. Number of publications over years.

As Figure 5 shows, researchers generally preferred qualitative approaches. The three most commonly used qualitative methods were systematic literature review, case studies, and interviews.

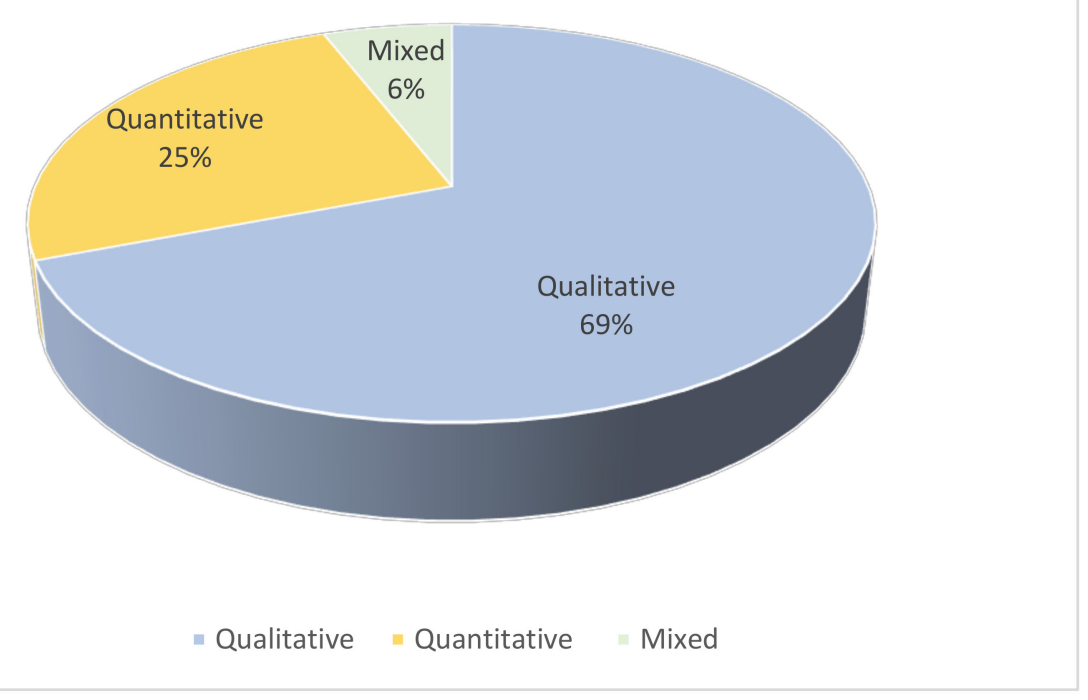

Figure 5. Methods used in publications.

Figure 6 shows the distribution of studies according to their focus on specific CE dimensions based on the 9R framework. $C E$ can be achieved by adapting 9R principles to the supply chain. The most frequently mentioned dimension was "rethinking", which indicates that overcoming $\mathrm{CE}$ barriers requires rethinking at the design stage. The three most frequently mentioned CE dimensions were rethink (28\%), recycle $(17 \%)$, and reuse 
$(16 \%)$ whereas the three least frequently mentioned were repair $(1 \%)$, refurbish $(2 \%)$, and recover $(6 \%)$.

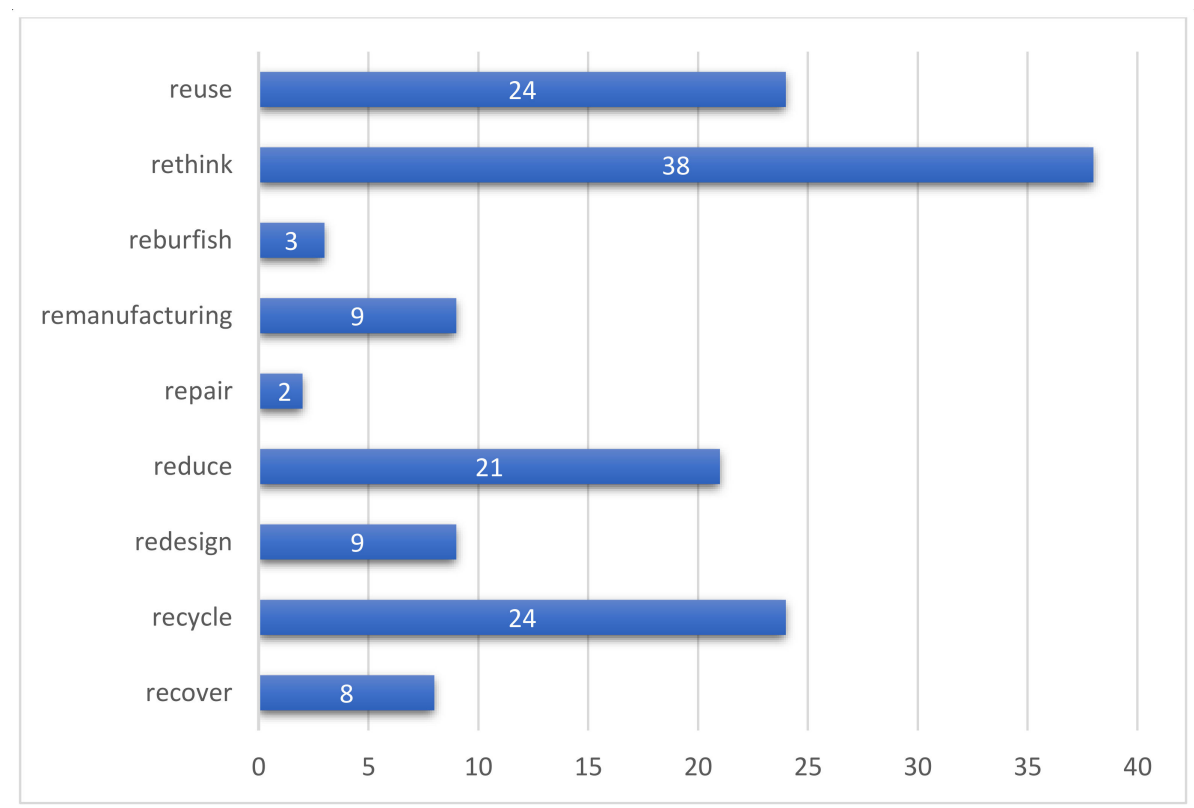

Figure 6. Number of publications based on CE dimensions.

Regarding supply chain stages (Figure 7), most articles (90) focused on consumption, followed by collection (15) and food processing (9). It is worth noting that no articles about barriers to CE in food supply chains focused on 'farm to factory', 'from production facility to retail', and 'packaging'. Similarly, 'reverse logistics', 'retail to market', 'harvesting', and 'collection' received minimal attention. This finding indicates that more research is needed into certain food chain stages to identify all the barriers to applying CE.

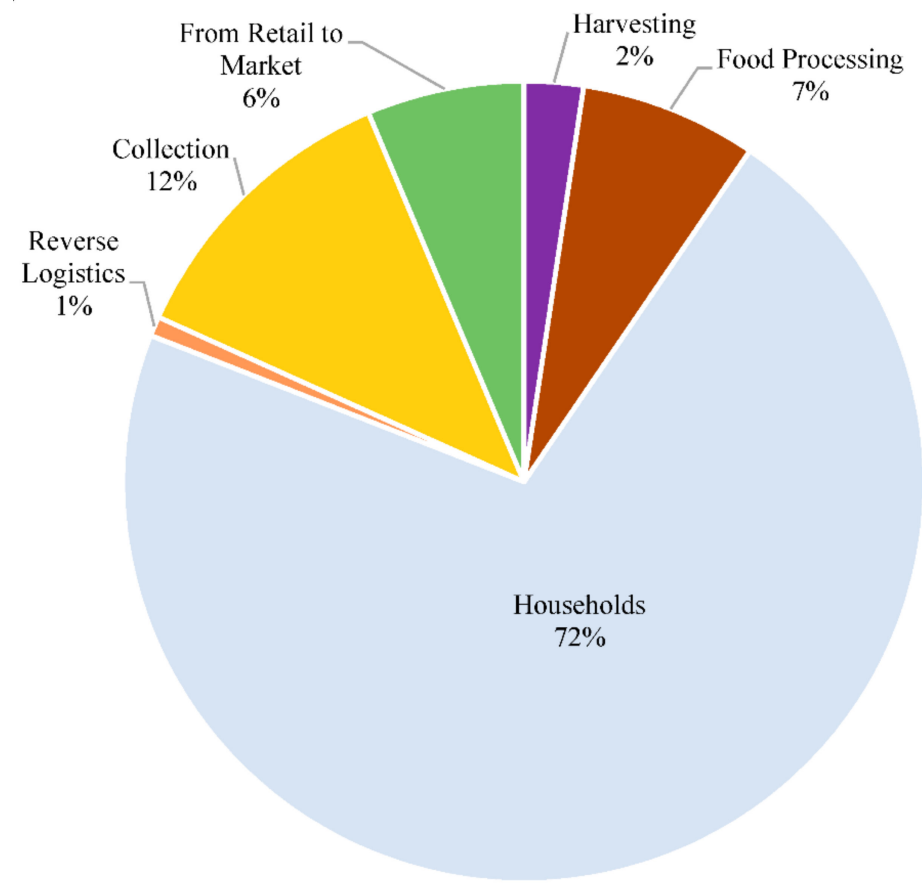

Figure 7. Distribution of articles focused on specific supply chain stages. 
Figure 8 shows which food sub-sectors have adopted CE dimensions in their food chains. The top sub-sector was fruit and vegetables (32\%), followed by milk and meat $(24 \%)$, wine $(20 \%)$, sugar $(12 \%)$, and coffee $(12 \%)$.

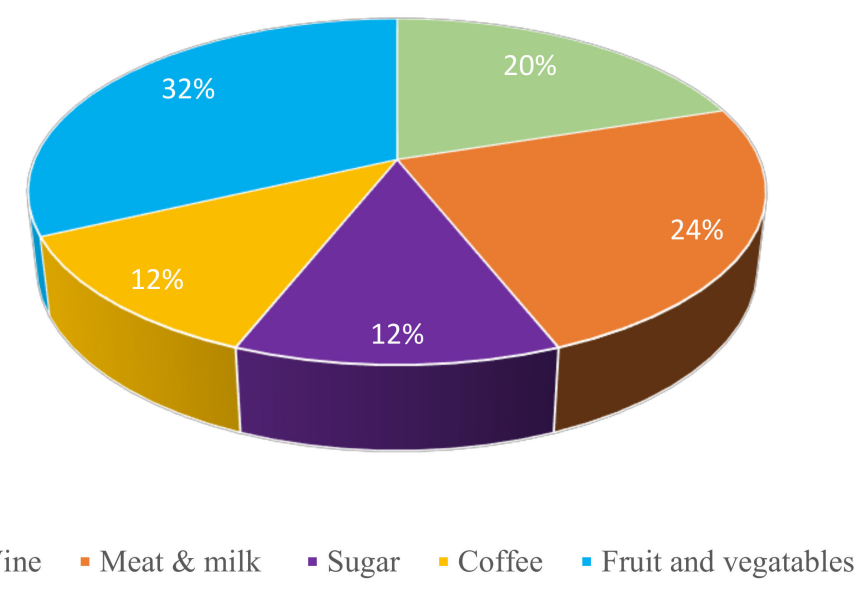

Figure 8. Distribution of food sub-sectors adaptation of CE dimensions.

Figure 9 shows the methodology used for studies of specific CE dimensions. Confirming Figure 5, qualitative methodology is most frequently used across all CE dimensions. In contrast, quantitative studies are very limited in this field.

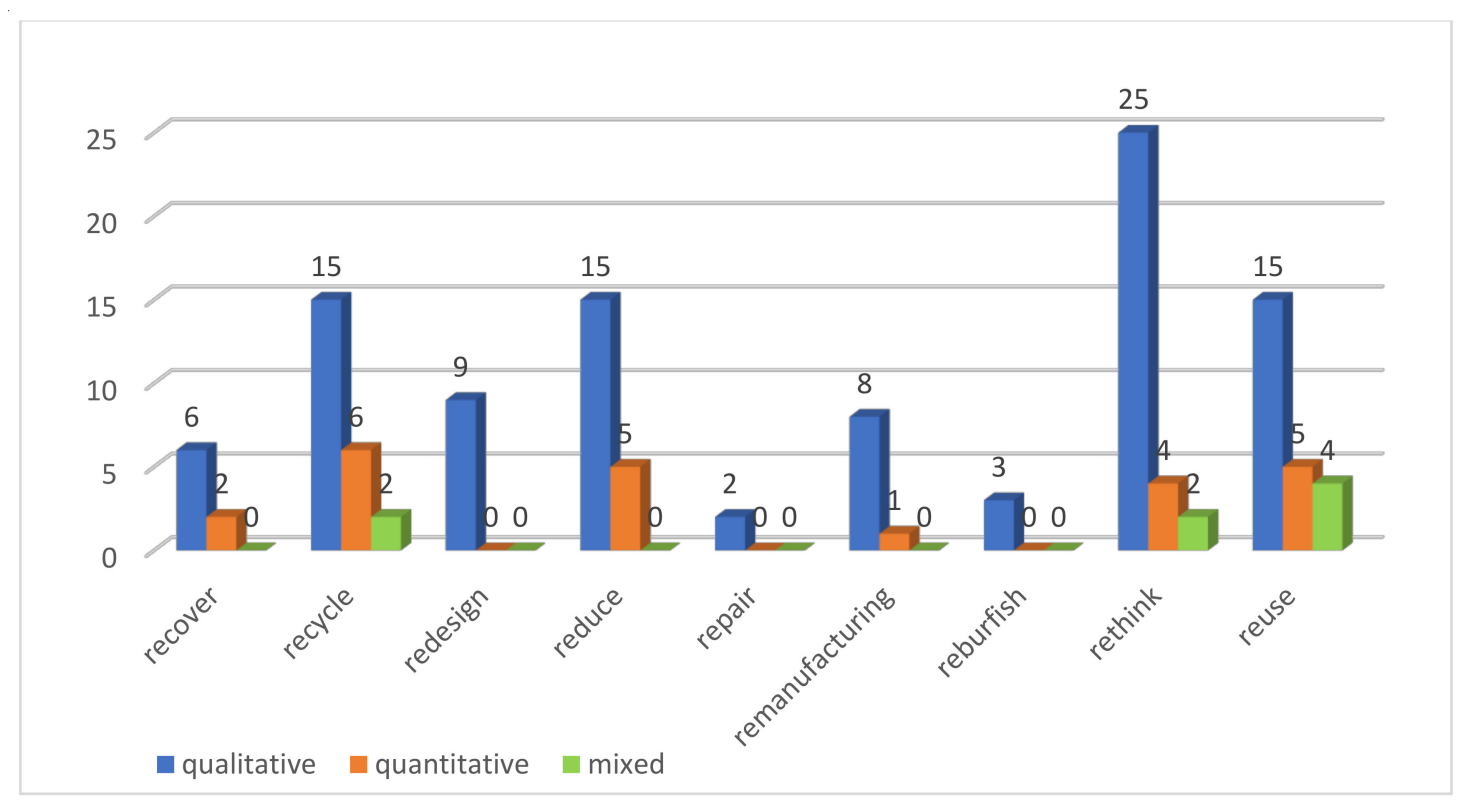

Figure 9. Relationship between methods and CE dimensions.

Figure 10 shows the relationship between the stage of the food chain that each article focused on and the CE dimension. The most commonly mentioned CE dimensions were rethink, reuse, and reduce. For household food waste and loss specifically, the findings indicate that all CE dimensions need to be considered and solutions developed in terms of all dimensions. 


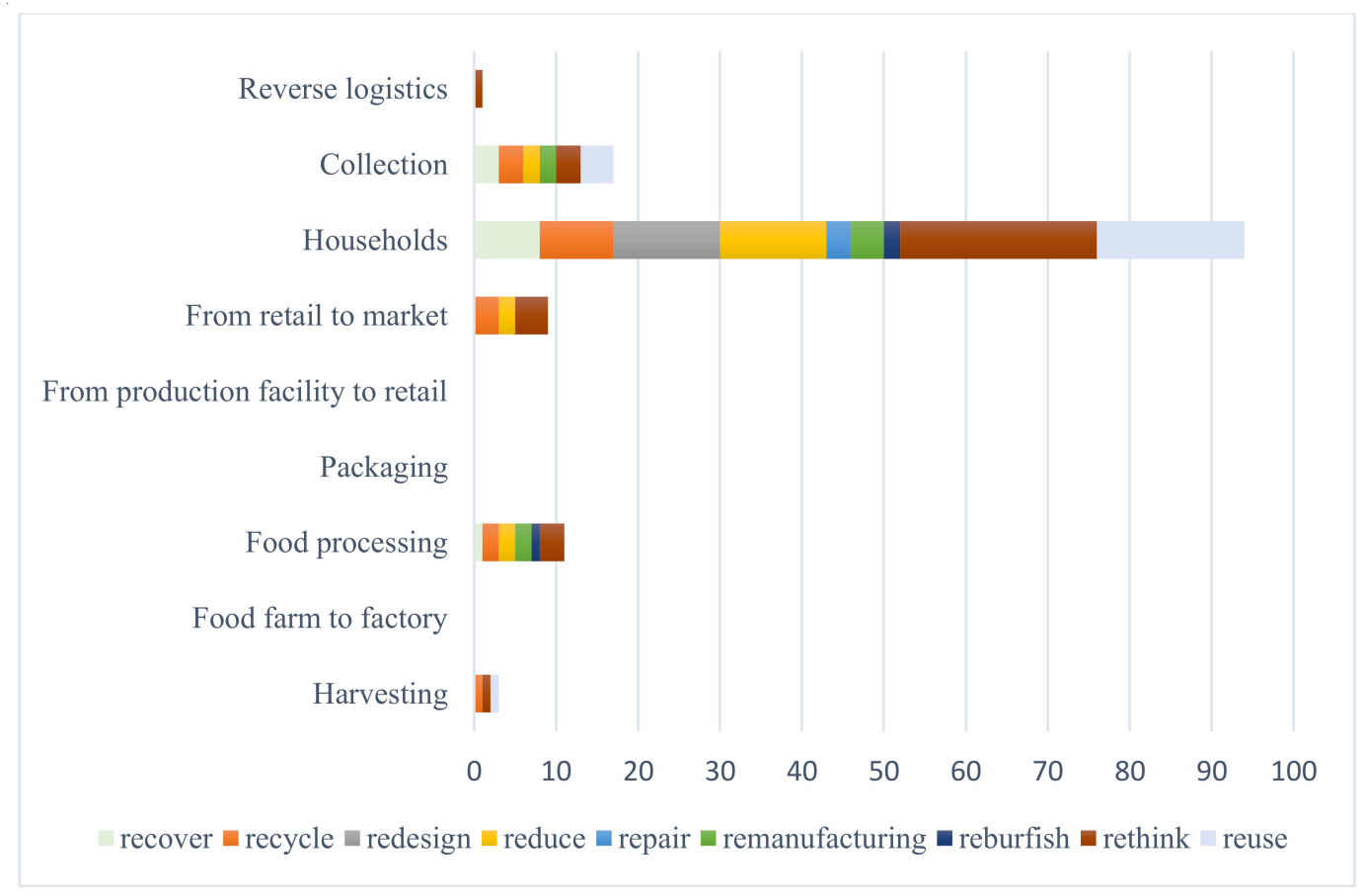

Figure 10. Relationship between stages of food supply chain and CE dimensions.

As Figure 11 shows, all food supply chain stages are critical for all of the different sub-sectors.

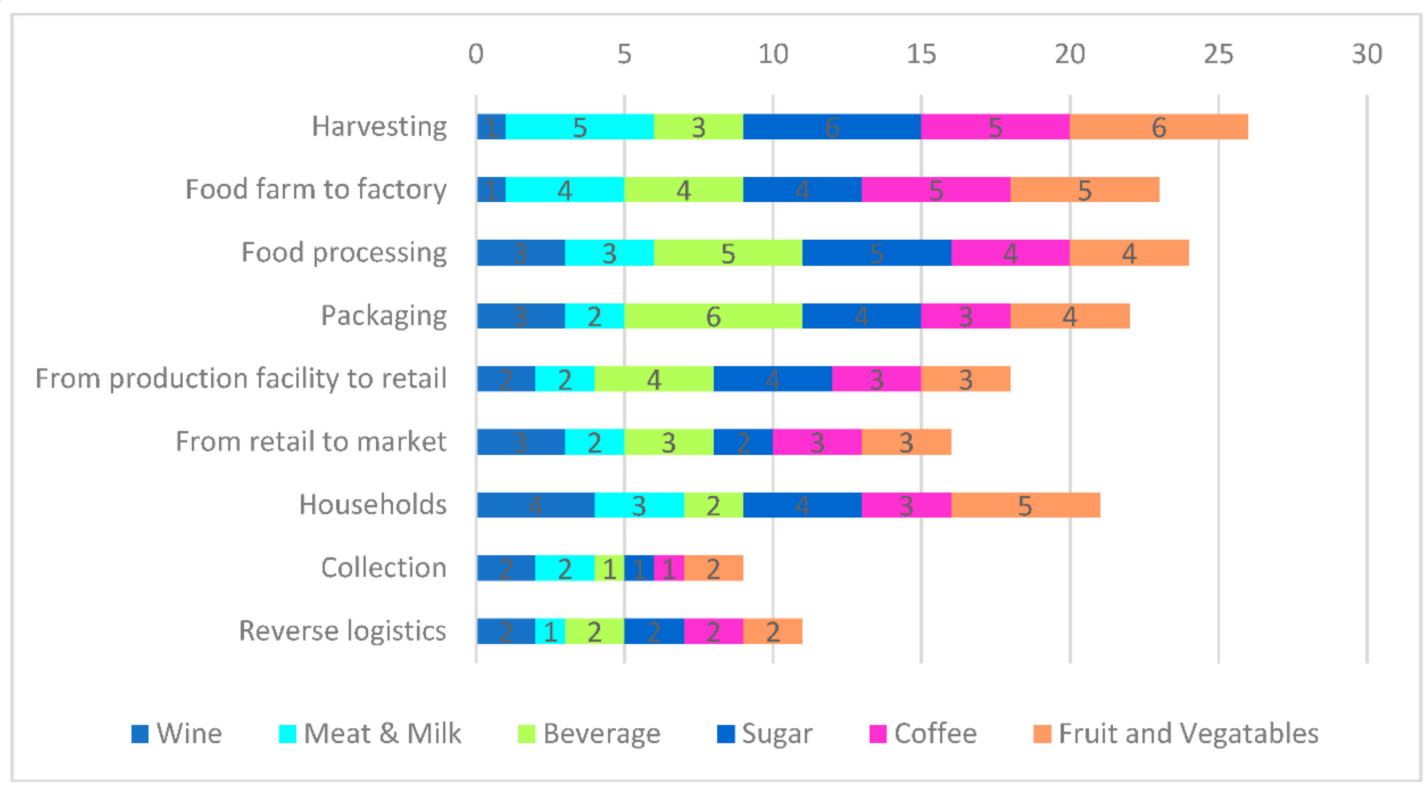

Figure 11. Relationship between sub-sectors and supply chain stages.

As shown in Figure 12, the selected articles focused most frequently on "recycle" and "reduce" for all sub-sectors. Apart from these CE dimensions, articles regarding the meat and milk sectors mainly focused on design stage dimensions of "redesign" and "rethink" to decrease food loss and waste. In contrast, no articles considered "repair" and "refurbishment". This may because reducing and recycling processes are more appropriate for the sampled sub-sectors. 


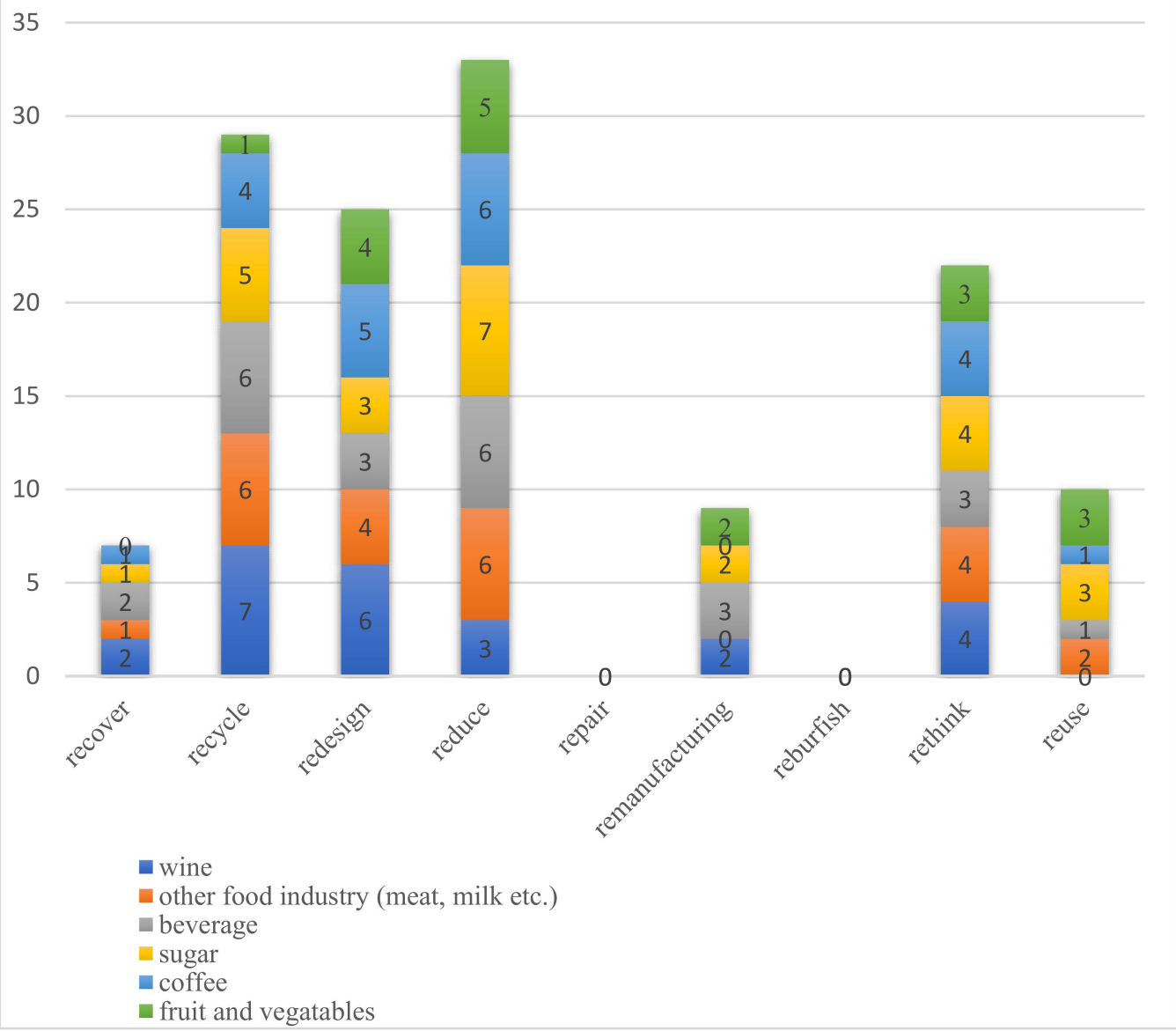

Figure 12. Relationship between sub-sectors and CE dimensions.

The findings so far show that researchers have discussed and categorized barriers to implementing CE bin food supply chains in various ways. Araujo Galvão [20] identified seven main barriers: technological, policy and regulatory, financial and economic, managerial, performance indicators, customers, and social. Govindan and Hasanagic [14] identified eight categories: governmental issues, economic issues, technology issues, knowledge issues, management issues, CE framework issues, cultural and social issues, and market issues. Kirchherr et al. [21] identified four categories: culture, regulatory, market, and technology. Ghadge et al. [22] first identified two barriers: internal and external. They then classified them into five different categories: market, regulation, suppliers, operation, and management. Van Keulen and Kirchherr [23] identified four main clusters of barriers in the coffee supply chain: values, technologies, business cases, and governmental policies.

Given this literature, the present study considered seven main barriers to $\mathrm{CE}$, as shown in Table 2: "cultural", "business and business finance", "regulatory and governmental", "technological", "managerial", "supply-chain management", "knowledge and skills". 
Table 2. Potential barriers of CE in food supply chains.

\begin{tabular}{|c|c|c|}
\hline Barriers & Sub-Barriers & Author(s) \\
\hline$\frac{\pi}{3}$ & $\begin{array}{l}\text { (B1) Lacking Consumer Awareness and Interest } \\
\text { (B2) Hesitant Company Culture } \\
\text { (B3) Inadequate Knowledge About CE } \\
\text { (B4) Currently Operating in a Linear System }\end{array}$ & $\begin{array}{c}{[11,13,24-52] .} \\
{[13,29-32,53]} \\
{[13,29,30,37,40,41,44,45,47-49,53-62]} \\
{[63,64]}\end{array}$ \\
\hline 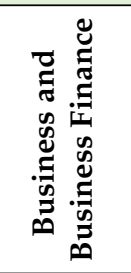 & $\begin{array}{l}\text { (B5) Weak Economic Incentives } \\
\text { (B6) Major Investment Costs } \\
\text { (B7) High Cost of Receiving Recycling Product } \\
\text { (B8) Mismatch between Return and Profit } \\
\text { (B9) Increased Research Cost } \\
\text { (B10) Limited Business Model Applications }\end{array}$ & $\begin{array}{c}27,41-48,60,65,66] \\
{[43,44,47,48,67,68]} \\
{[30,31,41,45,47,48,66]} \\
{[40,43,47,48]} \\
{[68]} \\
{[44,46]}\end{array}$ \\
\hline 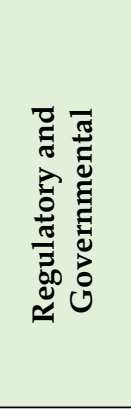 & $\begin{array}{c}\text { (B11) Lack of Conductive Legal Systems } \\
\text { (B12) Policy Challenges } \\
\text { (B13) Taxation and Incentives } \\
\text { (B14) Existing Loose Environmental Regulations } \\
\text { (B15) Different Focuses between Central and Local } \\
\text { Governments } \\
\text { (B16) Lack of Proper Waste Infrastructure } \\
\text { (B17) Lack of Standard System for CE performance }\end{array}$ & $\begin{array}{c}{[14,24,30,39,41,42,46-48,54]} \\
{[11,13,24-50,52] .} \\
{[14,41,45,47,48]} \\
{[25,27,36,61,69]} \\
{[38,52,70]} \\
{[38,42,56,58,59,71-74]} \\
{[25,32,38,44,47,48,53,55,56,58,59,71-77]}\end{array}$ \\
\hline 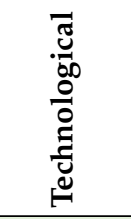 & $\begin{array}{c}\text { (B18) Technical Limitations of Recycling } \\
\text { (B19) Need for Data Integration } \\
\text { (B20) Lack of Eco-efficiency of the Technological } \\
\text { Processes }\end{array}$ & $\begin{array}{c}{[13,30,31,41,44,46-48,54,61,65,67]} \\
{[26,78]} \\
{[16,41,47,48,54,79]}\end{array}$ \\
\hline 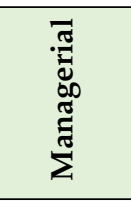 & $\begin{array}{l}\text { (B21) Poor Leadership and Management } \\
\text { (B22) Missing Information Exchange } \\
\text { (B23) Lack of Collaboration } \\
\text { (B24) Higher priority of other issues } \\
\text { (B25) Ineffective labor }\end{array}$ & $\begin{array}{r}{[11,12,25,28,31,32,34,42,44,47,48,80-83]} \\
{[11,47,48]} \\
{[12,15,24,34,41,44,45,47,61,76-78,80,83]} \\
{[47,84]} \\
{[18,68]} \\
\end{array}$ \\
\hline 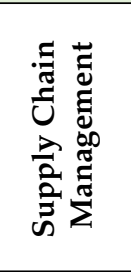 & $\begin{array}{c}\text { (B26) Lack of Eco-Literacy Among Supply Chain } \\
\text { Partners } \\
\text { (B27) Need for a High-Level Supply Chain } \\
\text { Integration } \\
\text { (B28) Unavailable Effective Framework } \\
\text { Adaptation }\end{array}$ & $\begin{array}{c}{[41,85,86]} \\
{[11,12,25,28,32,34,35,41,44,47,48,52,71,76,} \\
77,81,82,84,85,87-97] \\
{[48,80,98]}\end{array}$ \\
\hline 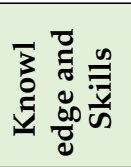 & $\begin{array}{c}\text { (B29) Difficulty in Defining CE } \\
\text { (B30) Difficulties in implementation of CE }\end{array}$ & $\begin{array}{c}{[32,44,99,100]} \\
{[32,44,47,99-103]}\end{array}$ \\
\hline
\end{tabular}

More specifically, "cultural barriers" include four different sub-barriers: lack of consumer awareness and interest, inadequate knowledge of $\mathrm{CE}$, hesitant company culture, currently operating in a linear system. The transition to $\mathrm{CE}$ requires remarkable cultural changes in company structure. The main barriers to $\mathrm{CE}$ implementation are regulatory barriers, which include policy challenges and the lack of a standard system for CE performance and supply, and chain management barriers such as the need for high-level supply chain integration. Moreover, technological investment and development is a significant factor in the transition to CE. Another main barrier is inadequate knowledge and skills. It is therefore important for companies to improve awareness of $\mathrm{CE}$ and integrate $\mathrm{CE}$ into their supply chains. Supply chain management barriers include a lack of eco-literacy among supply chain partners, the need for a high-level supply chain integration, and ineffective framework adaptation. Business and business finance sub-barriers include weak 
economic incentives, major investment costs, the high cost of receiving recycling products, a mismatch between return and profit, increased research costs, and limited business model applications. Business and business finance, and managerial barriers are also related to the significant initial investment and widening multi-stakeholder structure in the supply chain during the transition to CE. Increasing complexity and information in the supply chain also create new sub-barriers, such as poor leadership and management, lack of information exchange, lack of collaboration, prioritization of other issues, and ineffective labor.

Although some companies find it easier to maintain traditional production and distribution methods, many other companies have begun the CE transition. While some large firms, as well as some start-ups, have begun using CE principles, it will take time to shift the entire corporate culture towards this. In contrast to traditional business models, circular business models require novel cooperation and collaboration methods along the supply chain. Companies should therefore invest and innovate using CE principles. In this regard, it is important to design longer-lived, waste-avoiding products so that it is easy to apply the 9Rs. Accordingly, technical barriers include the transition to CE, technical limitations of recycling, the need for data integration, and lack of eco-efficiency of technological processes.

Regarding regulatory and local government barriers, CE implementation requires understanding the various expectations of different actors and clear regulatory standards. Thus, barriers include lack of appropriate legal systems, policy challenges, taxation and incentives, loose environmental regulations, different focuses between central and local governments, lack of proper waste infrastructure, and lack of standard systems for CE performance. Some actors may oppose CE because they profit highly from the existing linear system. Thus, it is crucial to have a clear regulatory framework.

Figure 13 shows the interaction between the sub-barriers and the stages of the supply chain. Almost all the articles mentioned various sub-barriers for different stages of the food supply chain, particularly lack of consumer awareness and interest, policy challenges, inadequate knowledge about $\mathrm{CE}$, weak economic incentives, lack of conducive legal systems, lack of standard CE performance systems, technical limitations for CE, and poor leadership and management. 


$\begin{array}{ll}\square \text { harvesting } & \text { food farm to factory } \\ \square \text { packaging } & \text { from production facility to retail } \\ \square \text { households } & \text { from retail to market }\end{array}$

(B1) Lacking Consumer Awareness \& Interest

(B2) Hesitant Company Culture

(B3) Inadequate Knowledge About CE

(B4) Currently Operating in a Linear System

(B5) Weak Economic Incentives

(B6) Major Invesment Costs

(B7) High Cost of Receiving Recycling Product

(B8) Mismatch between Return \& Profit

(B9) Increased Research Cost

(B10) Lack of Conductive Legal System...

(B11) Policy Challenges

(B12) Taxation \& Incentives

(B13) Existing Loose Environmental Regulations (B14) Different Focuses between Central \& Local Governments

(B15) Lack of Proper Waste Infrastructure (B16) Lack of Standard System for CE performance

(B17) Technical Limitations of Recycling (B18) Need for Data Integration

(B19) Limited Business Model Applications

(B20)Lack of Eco-efficiency of the Technological Processes

(B21) Poor Leadership \& Management

(B22) Missing Information Exchange

(B23) Lack of Collaboration

(B24) Higher Priority of Other Isssues

(B25) Ineffective Labor

(B26) Lack of Eco-Literacy Among Supply Chain Partners

(B27) Need for a High Level Supply Chain Integration

(B28) Unavailable Effective Framework Adaptation

(B29) Difficulty in Defining CE

(B30) Difficulties in implementation of CE

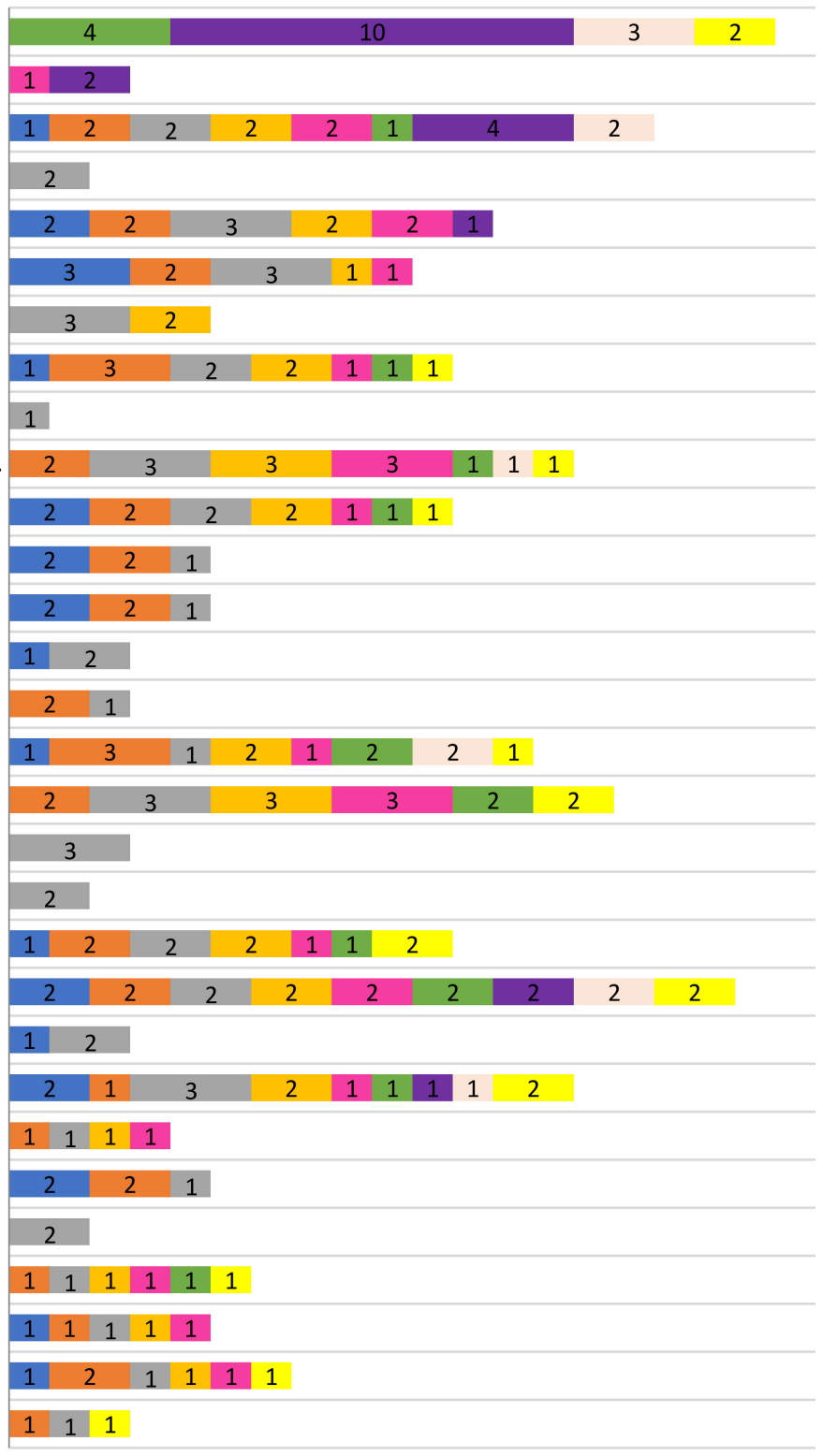

Figure 13. Interaction between sub-barriers and supply chain stages.

Figure 14 shows the interaction between sub-barriers and CE dimensions. Rethink and reduce were the most frequently mentioned in the articles $\mathrm{CE}$ dimensions for nearly all sub-barriers to implementing $\mathrm{CE}$ in the food supply chain, followed by use of recycling. 


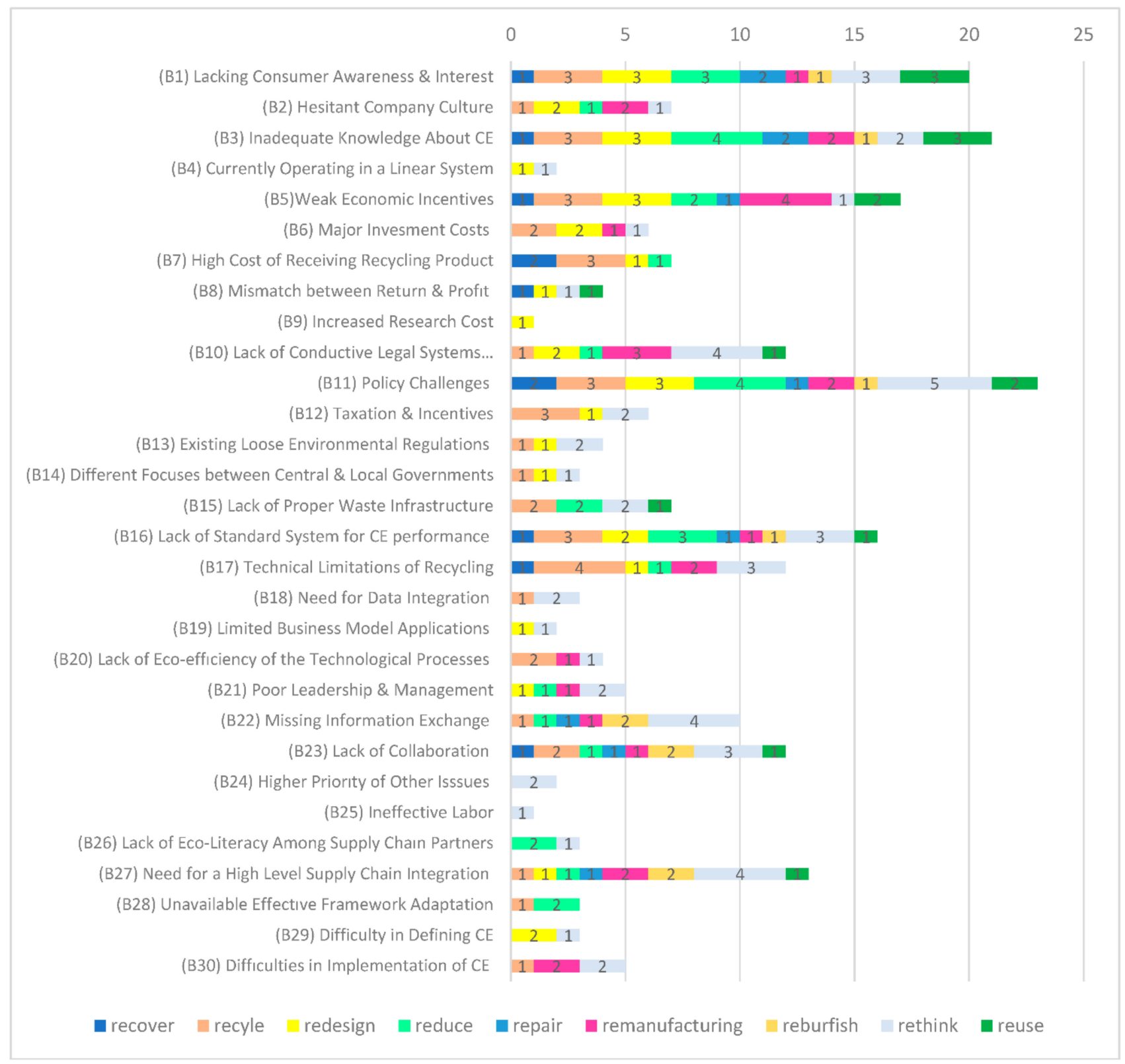

Figure 14. Interaction between sub-barriers and CE dimensions.

\subsection{Relationships Between CE and Digital Technologies}

Researchers have proposed various Industry 4.0 technologies to overcome the subbarriers to CE in food supply chains. Digital technologies have various advantages. First, by obtaining real-time information, they can improve performance by ensuring efficient utilization of resources. Second, these technologies can improve the innovation abilities of businesses.

Table 3 lists various digital technologies for overcoming CE-related barriers. IoT and barcodes are used to monitor used product parts and materials, obtain all information about products, and reduce product design or quality issues [104]. In the food industry specifically, IoT can reduce food waste and loss through sensors that track conditions in the food supply chain, such as temperature and humidity. Recent studies show that IoT strategies can improve product design and implementation [105]. IoT can also be used to create business models, usage and post-usage improvements, data recording, monitoring of conditions, preventive maintenance, predictions for end-of-life usage, and making 
effective design decisions [17]. Real time data allow consumers to assess food quality more accurately and create a better health and safety environment since food products usually have short shelf lives. Increasing traceability saves energy in the food supply chain and creates circularity. Digital tools that provide traceability, such as RFID, BDA, and blockchains, can be used for the recovery processes, such as reusing, recycling, and remanufacturing [106]. If all stakeholders can share their data in the supply chain network, then food fraud can be reduced with blockchain technology.

Table 3. Proposed digital technologies to deal with barriers related to CE dimensions.

\begin{tabular}{cc}
\hline CE DIMENSIONS & INDUSTRY 4.0 TECHNOLOGIES \\
\hline Reuse & $\begin{array}{c}\text { CPS, BDA, AI, 3DP, RFID, Barcodes, } \\
\text { Nanotechnologies, Blockchain }\end{array}$ \\
\hline Recycle & $\begin{array}{c}\text { IoT, CPS, BDA, CC, AI,3DP, RFID, Barcodes, } \\
\text { Blockchain }\end{array}$ \\
\hline Reduce & IoT, 3DP \\
\hline Remanufacturing & IoT, BDA, CC, AI, 3DP, RFID, Barcodes, Robotics \\
\hline Repair & CC CPS, BDA, 3DP \\
\hline Recover & CPS, AI \\
\hline Refurbish & Machine Learning \\
\hline Repurpose & AGV, Machine Learning \\
\hline Rethink & Iot, AGV, Machine Learning \\
\hline Redesign &
\end{tabular}

One of the most important causes of food waste is supply-demand imbalance. CPS technology helps suppliers to determine optimum order size by gathering data from transactions and other sources in to accurately monitor in-process inventory [107]. 3DP technology enables the reuse of material for another 3DP process and strengthens the relationship between suppliers and customers [108]. 3DP is a flexible technology, which enables the production of both small batches and complex products at lower cost, fewer materials, and less waste [109]. 3DP technology provides design for circularity and environmentally friendly materials. It enables intelligent packaging for food products by analyzing and indicating the temperature of the product to decrease food waste and loss. Machine learning and AI can be used to overcome the CE barriers in the supply chain by optimizing processes and systems based on large amounts of data in order to repurpose, rethink, and redesign CE dimensions [16]. CC enables sharing of network resources and capabilities in certain supply chain stages, particularly design, manufacture, and assembly of products $[110,111]$. Robotics provides additional support by supporting processes that require quality production and precision in production. It can therefore be used for remanufacturing processes in the supply chain [112]. Businesses have already used robotics to increase food product consistency and production efficiency. Finally, nanotechnologies, $\mathrm{AGV}$, and machine learning enable materials and components to be recycled in the last stage of product life and reused within the same production system or outside it [113].

Table 4 summarizes how Industry 4.0 technologies mentioned in the literature can deal with barriers related to specific CE dimensions. Digital technology tools are proposed for each sub-barrier within the dimensions listed in Table 3. 
Table 4. Proposed Industry 4.0 technologies to deal with sub-barriers for specific CE dimensions.

\begin{tabular}{|c|c|c|c|c|}
\hline Main Barriers & Sub-Barriers & Author(s) & CE Dimensions & $\begin{array}{l}\text { Industry } 4.0 \\
\text { Technologies }\end{array}$ \\
\hline \multirow{4}{*}{ Cultural } & $\begin{array}{l}\text { (B1) Lacking consumer } \\
\text { awareness and interest }\end{array}$ & $\begin{array}{c}{[114,116,119,122,132,} \\
136,138,139]\end{array}$ & $\begin{array}{c}\text { Reuse, Recycle, Reduce, } \\
\text { Rethink, } \\
\text { Remanufacturing, } \\
\text { Redesign, Repair, } \\
\text { Refurbish }\end{array}$ & $\begin{array}{c}\text { IoT, CPS, BDA, CC, AI, } \\
\text { 3DP, RFID, Barcodes, } \\
\text { Robotics, Blockchains, } \\
\text { AGV, Machine learning, } \\
\text { Nanotechnology }\end{array}$ \\
\hline & $\begin{array}{l}\text { (B2) Hesitant company } \\
\text { culture }\end{array}$ & $\begin{array}{c}{[121,130,132,134,138,} \\
140]\end{array}$ & $\begin{array}{l}\text { Reuse, Recycle, Reduce, } \\
\text { Remanufacturing, } \\
\text { Repair, Refurbish }\end{array}$ & $\begin{array}{c}\text { IoT, CPS, BDA, CC, AI, } \\
\text { 3DP, RFID, Barcodes, } \\
\text { Robotics, Blockchains, } \\
\text { Nanotechnology }\end{array}$ \\
\hline & $\begin{array}{c}\text { (B3) Inadequate } \\
\text { knowledge about CE }\end{array}$ & {$[118,127,132,138,141]$} & $\begin{array}{c}\text { Reuse, Recycle, Reduce, } \\
\text { Remanufacturing, } \\
\text { Repair, Refurbish, } \\
\text { Rethink }\end{array}$ & $\begin{array}{c}\text { IoT, CPS, BDA, CC, AI, } \\
\text { 3DP, RFID, Barcodes, } \\
\text { Robotics, Blockchains, } \\
\text { AGV, Machine learning, } \\
\text { Nanotechnology }\end{array}$ \\
\hline & $\begin{array}{l}\text { (B4) Currently } \\
\text { operating in a linear } \\
\text { system }\end{array}$ & {$[123,129,132,135,140]$} & Reuse, Reduce, Rethink & $\begin{array}{c}\text { IoT, CPS, BDA, AI, 3DP, } \\
\text { RFID, Barcodes, } \\
\text { Blockchains, AGV, } \\
\text { Machine learning, } \\
\text { Nanotechnology }\end{array}$ \\
\hline \multirow{6}{*}{$\begin{array}{l}\text { Business and Business } \\
\text { Finance }\end{array}$} & $\begin{array}{l}\text { (B5) Weak economic } \\
\text { incentives }\end{array}$ & $\begin{array}{c}{[121,128,132,136,138,} \\
139]\end{array}$ & $\begin{array}{l}\text { Reuse, Recycle, Reduce, } \\
\text { Remanufacturing, } \\
\text { Repair, Refurbish, } \\
\text { Rethink, Redesign }\end{array}$ & $\begin{array}{c}\text { IoT, CPS, BDA, CC, AI, } \\
\text { 3DP, RFID, Barcodes, } \\
\text { Robotics, Blockchains, } \\
\text { AGV, Machine learning, } \\
\text { Nanotechnology }\end{array}$ \\
\hline & $\begin{array}{l}\text { (B6) Major investment } \\
\text { costs }\end{array}$ & {$[129,139]$} & Repurpose, Rethink & $\begin{array}{l}\text { AGV, Machine } \\
\text { Learning }\end{array}$ \\
\hline & $\begin{array}{l}\text { (B7) High cost of } \\
\text { receiving recycling } \\
\text { product }\end{array}$ & {$[128,140]$} & Rethink & $\begin{array}{l}\text { AGV, Machine } \\
\text { Learning }\end{array}$ \\
\hline & $\begin{array}{l}\text { (B8) Mismatch between } \\
\text { return and profit }\end{array}$ & {$[128,129]$} & Rethink & $\begin{array}{l}\text { AGV, Machine } \\
\text { Learning }\end{array}$ \\
\hline & $\begin{array}{c}\text { (B9) Increased research } \\
\text { cost }\end{array}$ & {$[128,141]$} & Repurpose, Rethink & $\begin{array}{l}\text { AGV, Machine } \\
\text { Learning }\end{array}$ \\
\hline & $\begin{array}{l}\text { (B10) Limited business } \\
\text { model applications }\end{array}$ & {$[132,135,137,141]$} & Repair, Rethink & $\begin{array}{c}\text { IoT, CPS, BDA, 3DP, } \\
\text { AGV, Machine learning }\end{array}$ \\
\hline \multirow{3}{*}{$\begin{array}{l}\text { Regulatory and } \\
\text { Governmental }\end{array}$} & $\begin{array}{c}\text { (B11) Lack of } \\
\text { conductive legal } \\
\text { systems }\end{array}$ & $\begin{array}{c}{[108,117,120,128,130} \\
132,138]\end{array}$ & $\begin{array}{c}\text { Reuse, Recycle, Reduce, } \\
\text { Remanufacturing, } \\
\text { Repair, Refurbish, } \\
\text { Rethink }\end{array}$ & $\begin{array}{c}\text { IoT, CPS, BDA, CC, AI, } \\
\text { 3DP, RFID, Barcodes, } \\
\text { Robotics, Blockchains, } \\
\text { AGV, Machine learning, } \\
\text { Nanotechnology }\end{array}$ \\
\hline & (B12) Policy challenges & $\begin{array}{c}{[116,119,125,131-} \\
133,138]\end{array}$ & $\begin{array}{c}\text { Reuse, Recycle, Reduce, } \\
\text { Remanufacturing, } \\
\text { Repair, Recover, } \\
\text { Refurbish, Rethink, } \\
\text { Redesign }\end{array}$ & $\begin{array}{c}\text { IoT, CPS, BDA, AI, 3DP, } \\
\text { CC, Blockchains, } \\
\text { Robotics, AGV, } \\
\text { Machine Learning }\end{array}$ \\
\hline & $\begin{array}{l}\text { (B13) Taxation and } \\
\text { incentives }\end{array}$ & $\begin{array}{c}{[115,116,127-} \\
129,132,136,138]\end{array}$ & $\begin{array}{c}\text { Reuse, Recycle, Reduce, } \\
\text { Rethink }\end{array}$ & $\begin{array}{c}\text { IoT, CPS, BDA, CC, AI, } \\
\text { 3DP, RFID, Barcodes, } \\
\text { Robotics, Blockchains, } \\
\text { AGV, Machine learning, } \\
\text { Nanotechnology }\end{array}$ \\
\hline
\end{tabular}


Table 4. Cont

\begin{tabular}{|c|c|c|c|c|}
\hline Main Barriers & Sub-Barriers & Author(s) & CE Dimensions & $\begin{array}{l}\text { Industry } 4.0 \\
\text { Technologies }\end{array}$ \\
\hline & $\begin{array}{l}\text { (B14) Existing loose } \\
\text { environmental } \\
\text { regulations }\end{array}$ & $\begin{array}{c}{[116,126,131,132,134,} \\
138,139]\end{array}$ & $\begin{array}{l}\text { Reuse, Recycle, Reduce, } \\
\text { Recover, Rethink }\end{array}$ & $\begin{array}{c}\text { IoT, CPS, BDA, CC, AI, } \\
\text { 3DP, RFID, Barcodes, } \\
\text { Robotics, Blockchains, } \\
\text { AGV, Machine learning, } \\
\text { Nanotechnology }\end{array}$ \\
\hline & $\begin{array}{l}\text { (B15) Different focuses } \\
\text { between central and } \\
\text { local governments }\end{array}$ & $\begin{array}{c}{[116,124,129,132,135,} \\
138]\end{array}$ & $\begin{array}{l}\text { Reuse, Recycle, Reduce, } \\
\text { Remanufacturing, } \\
\text { Repair, Rethink }\end{array}$ & $\begin{array}{c}\text { IoT, CPS, BDA, CC, AI, } \\
\text { 3DP, Robotics, } \\
\text { Blockchains, AGV, } \\
\text { Machine learning }\end{array}$ \\
\hline & $\begin{array}{l}\text { (B16) Lack of proper } \\
\text { waste infrastructure }\end{array}$ & {$[116,129,137]$} & Rethink, Reduce & $\begin{array}{c}\text { IoT, AGV, 3DP, } \\
\text { Machine learning }\end{array}$ \\
\hline & $\begin{array}{l}\text { (B17) Lack of standard } \\
\text { system for CE } \\
\text { performance }\end{array}$ & $\begin{array}{c}{[116,120,123,129,132,} \\
135,138]\end{array}$ & $\begin{array}{c}\text { Reuse, Recycle, Reduce, } \\
\text { Remanufacturing, } \\
\text { Recover, Refurbish, } \\
\text { Rethink }\end{array}$ & $\begin{array}{c}\text { IoT, CPS, BDA, CC, AI, } \\
\text { 3DP, RFID, Barcodes, } \\
\text { Robotics, Blockchains, } \\
\text { AGV, Machine learning, } \\
\text { Nanotechnology }\end{array}$ \\
\hline \multirow{3}{*}{ Technological } & $\begin{array}{c}\text { (B18) Technical } \\
\text { limitations of recycling }\end{array}$ & {$[121,132,137-139]$} & $\begin{array}{l}\text { Reuse, Recycle, Reduce, } \\
\text { Remanufacturing, } \\
\text { Repair, Refurbish, } \\
\text { Rethink, Redesign }\end{array}$ & $\begin{array}{c}\text { IoT, CPS, BDA, CC, AI, } \\
\text { 3DP, RFID, Barcodes, } \\
\text { Robotics, Blockchains, } \\
\text { AGV, Machine learning, } \\
\text { Nanotechnology }\end{array}$ \\
\hline & $\begin{array}{l}\text { (B19) Need for data } \\
\text { integration }\end{array}$ & {$[132-134,141]$} & $\begin{array}{l}\text { Reuse, Recycle, Reduce, } \\
\text { Rethink }\end{array}$ & $\begin{array}{c}\text { IoT, CPS, BDA, CC, AI, } \\
\text { 3DP, RFID, Barcodes, } \\
\text { Blockchains, AGV, } \\
\text { Machine learning, } \\
\text { Nanotechnology }\end{array}$ \\
\hline & $\begin{array}{c}\text { (B20) Lack of } \\
\text { eco-efficiency of the } \\
\text { technological processes }\end{array}$ & $\begin{array}{c}{[120,123,129,132,137,} \\
138]\end{array}$ & $\begin{array}{l}\text { Reuse, Recycle, } \\
\text { Remanufacturing, } \\
\text { Rethink }\end{array}$ & $\begin{array}{c}\text { IoT, CPS, BDA, CC, AI, } \\
\text { 3DP, RFID, Barcodes, } \\
\text { Robotics, Blockchains, } \\
\text { AGV, Machine learning, } \\
\text { Nanotechnology }\end{array}$ \\
\hline \multirow{5}{*}{ Managerial } & $\begin{array}{l}\text { (B21) Poor leadership } \\
\text { and management }\end{array}$ & {$[116,132,136,138,140]$} & $\begin{array}{c}\text { Reuse, Recycle, Reduce, } \\
\text { Remanufacturing, } \\
\text { Repair, Recover, } \\
\text { Rethink }\end{array}$ & $\begin{array}{c}\text { IoT, CPS, BDA, CC, AI, } \\
\text { 3DP, RFID, Barcodes, } \\
\text { Robotics, Blockchains, } \\
\text { AGV, Machine learning, } \\
\text { Nanotechnology }\end{array}$ \\
\hline & $\begin{array}{l}\text { (B22) Missing } \\
\text { information exchange }\end{array}$ & {$[115,116,132,138,140]$} & $\begin{array}{c}\text { Reuse, Recycle, } \\
\text { Remanufacturing, } \\
\text { Repair }\end{array}$ & $\begin{array}{l}\text { IoT, CPS, BDA, CC, AI, } \\
\text { 3DP, RFID, Barcodes, } \\
\text { Robotics, Blockchains, } \\
\text { Nanotechnology }\end{array}$ \\
\hline & $\begin{array}{l}\text { (B23) Lack of } \\
\text { collaboration }\end{array}$ & {$[108,114,116,132,138]$} & $\begin{array}{l}\text { Reuse, Recycle, Reduce, } \\
\text { Rethink, Redesign }\end{array}$ & $\begin{array}{c}\text { IoT, CPS, BDA, CC, AI, } \\
\text { 3DP, RFID, Barcodes, } \\
\text { Blockchains, AGV, } \\
\text { Machine learning, } \\
\text { Nanotechnology }\end{array}$ \\
\hline & $\begin{array}{l}\text { (B24) Higher priority of } \\
\text { other issues }\end{array}$ & {$[128,129,141]$} & Rethink & AGV, Machine learning \\
\hline & (B25) Ineffective labor & {$[131,132,139]$} & Repurpose, Rethink & AGV, Machine learning \\
\hline
\end{tabular}


Table 4. Cont.

\begin{tabular}{|c|c|c|c|c|}
\hline Main Barriers & Sub-Barriers & Author(s) & CE Dimensions & $\begin{array}{l}\text { Industry } 4.0 \\
\text { Technologies }\end{array}$ \\
\hline \multirow{3}{*}{$\begin{array}{l}\text { Supply chain } \\
\text { management }\end{array}$} & $\begin{array}{c}\text { (B26) Lack of } \\
\text { eco-literacy among } \\
\text { supply-chain partners }\end{array}$ & {$[129,132,141]$} & $\begin{array}{c}\text { Reuse, Recycle, Reduce, } \\
\text { Rethink }\end{array}$ & $\begin{array}{c}\text { IoT, CPS, BDA, CC, AI, } \\
\text { 3DP, RFID, Barcodes, } \\
\text { Blockchains, AGV, } \\
\text { Machine learning, } \\
\text { Nanotechnology }\end{array}$ \\
\hline & $\begin{array}{l}\text { (B27) Need for a } \\
\text { high-level supply chain } \\
\text { integration }\end{array}$ & {$[114,132,135,138,141]$} & $\begin{array}{c}\text { Reuse, Recycle, Reduce, } \\
\text { Remanufacturing, } \\
\text { Repair, Recover, } \\
\text { Rethink }\end{array}$ & $\begin{array}{c}\text { IoT, CPS, BDA, CC, AI, } \\
\text { 3DP, RFID, Barcodes, } \\
\text { Robotics, Blockchains, } \\
\text { AGV, Machine learning, } \\
\text { Nanotechnology }\end{array}$ \\
\hline & $\begin{array}{l}\text { (B28) Unavailable } \\
\text { effective framework } \\
\text { adaptation }\end{array}$ & {$[132,133,135,140]$} & $\begin{array}{c}\text { Reuse, Recycle, Reduce, } \\
\text { Rethink }\end{array}$ & $\begin{array}{l}\text { IoT, CPS, BDA, CC, AI, } \\
\text { 3DP, RFID, Barcodes, } \\
\text { Blockchains, AGV, } \\
\text { Machine learning, } \\
\text { Nanotechnology }\end{array}$ \\
\hline \multirow[b]{2}{*}{ Knowledge and Skills } & $\begin{array}{l}\text { (B29) Difficulty in } \\
\text { defining CE }\end{array}$ & {$[132,138,140]$} & $\begin{array}{c}\text { Reuse, Recycle, Reduce, } \\
\text { Remanufacturing, } \\
\text { Refurbish, Repurpose, } \\
\text { Rethink }\end{array}$ & $\begin{array}{c}\text { IoT, CPS, BDA, CC, AI, } \\
\text { 3DP, RFID, Barcodes, } \\
\text { Robotics, Blockchains, } \\
\text { AGV, Machine learning, } \\
\text { Nanotechnology }\end{array}$ \\
\hline & $\begin{array}{l}\text { (B30) Difficulties in } \\
\text { implementation of CE }\end{array}$ & {$[123,132,134,136,138]$} & $\begin{array}{l}\text { Reuse, Recycle, Reduce, } \\
\text { Remanufacturing, } \\
\text { Refurbish, Rethink }\end{array}$ & $\begin{array}{c}\text { IoT, CPS, BDA, CC, AI, } \\
\text { 3DP, RFID, Barcodes, } \\
\text { Robotics, Blockchains, } \\
\text { AGV, Machine learning, } \\
\text { Nanotechnology }\end{array}$ \\
\hline
\end{tabular}

IoT, RFID, and Barcodes provide various advantages such as improved food supply chain transparency, improved inventory management by tracking the entire process, and enabling of real-time data for the food supply chains such as temperature and moisture $[108,114,115]$. By increasing transparency and collaborations in the food supply chain, IoT and RFID can be overcome regulatory and governmental barriers listed in Table 4. Besides, food supply chain transparency becomes a significant issue for the food supply chain because of the short shelf life since consumers want to know the process of products and choose a more environmentally friendly product [116-118]. Thus, IoT, RFID, and Barcodes are beneficial to deal with lacking consumer awareness and interest and inadequate knowledge about CE.

In addition, blockchain technology and CC enable the creation of a traceable and transparent food supply chain that increases trust between farmers, retailers, suppliers, and consumers, thus reducing food fraud [119-121]. Therefore, these technologies can overcome barriers related to regulatory and governmental issues. Blockchain technology can deal with the lack of collaboration and missing information exchange and weak economic incentives through increasing transparency [122-124]. Besides, an ascending collaboration between partners has led to increasing food supply chain practices, strategies, production processes [125-127].

Machine learning, AI, and CPS technology provide an increase in financial performances for each actor along the food supply chain [128] by enabling a higher degree of supply chain integration due to its multi-stakeholder structure and also contributing to the increase of environmental sustainability of the food supply chain $[129,130]$. Therefore, it is useful for dealing with financial challenges and ineffective labor in the transition to CE [131,132]. Moreover, big data are used to accurately forecast consumer demand and purchases by supporting increased coordination in the food supply chain in order to overcome data integration barriers in the food supply chain $[133,134]$. These technologies 
create new business models aimed at increasing the profitability of the company by reshaping its food supply chain operations. Thus, these technologies became a highly effective solution to dealing with the barriers faced by company cultures in transitioning to CE [135]. 3DP technology can reduce production costs by increasing production efficiency and by providing customized food product manufacturing [136]. 3DP technology enables the advantages of low cost and simple and rapid prototyping compared to traditional methods for the production of food materials. Thus, it is beneficial for dealing with the technical limitations of recycling and the lack of eco-efficiency of the technological processes [137].

AGV and Robotics help to achieve the goals of consumers and regulators to reduce food contamination and improve food safety [138]. These technologies enhance flexibility and can be used for multiple tasks in order to deal with the need for a high-level supply chain integration and difficulties in knowledge and skills.

Figure 15 presents the suggested Industry 4.0 technologies for each CE sub-barrier in the food supply chain, shown in Table 3. The barriers can be overcome with proposed Industry 4.0 technologies to transition to $\mathrm{CE}$ within food supply chains.

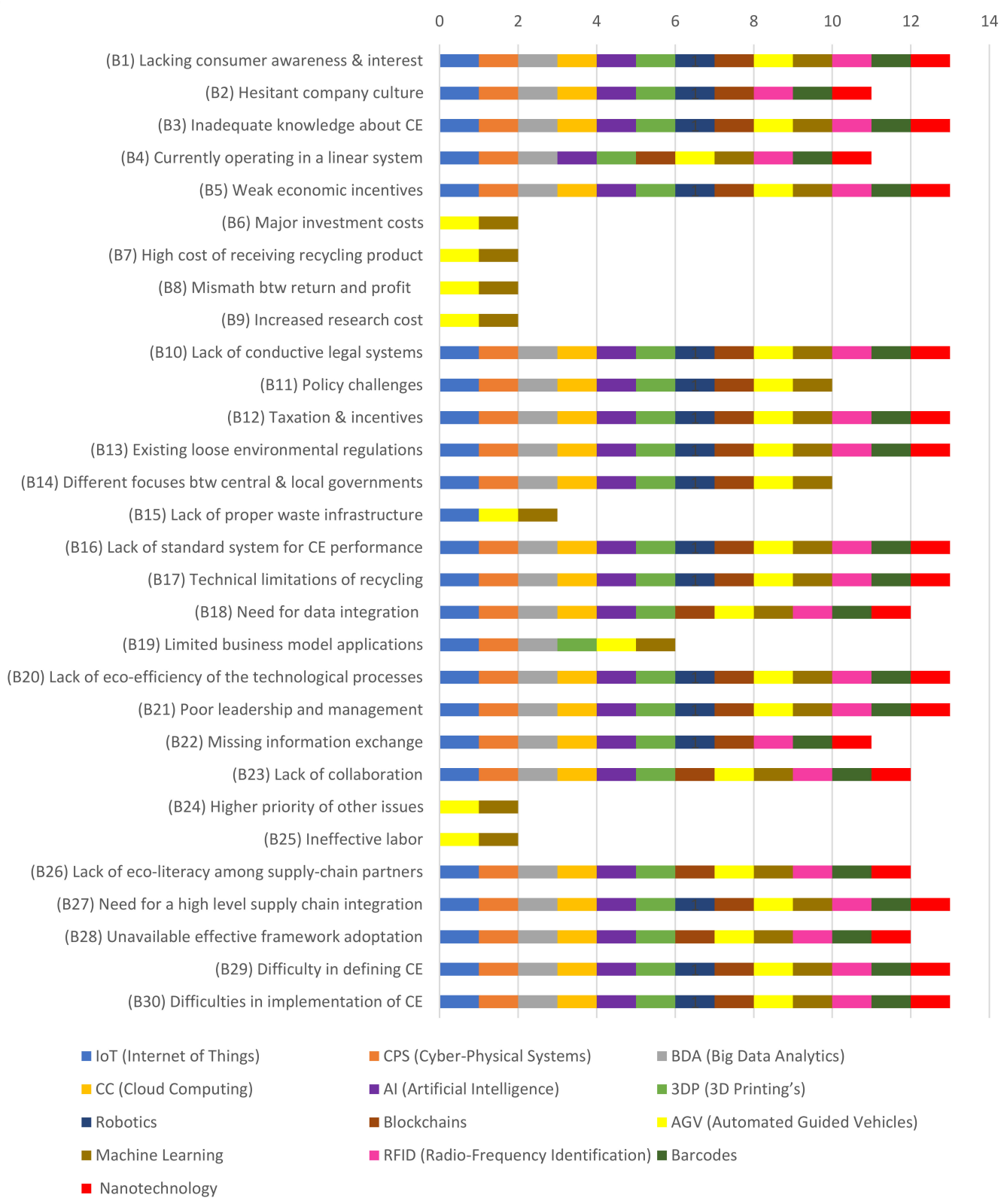

Figure 15. Interaction between sub-barriers and Industry 4.0 technologies. 


\section{Discussion}

The main contribution of this study to the literature is primarily to investigate the main barriers to CE implementation in the food supply chain by providing a systematic analysis on CE barriers in food supply chains. Then, this study is to highlight the importance of digital technologies to overcome $\mathrm{CE}$ challenges in circular food supply chains.

This study firstly conducted a content analysis of research articles investigating barriers to implementing $\mathrm{CE}$ in food supply chains. Based on this literature, the analysis identified seven main categories: "cultural", "business and business finance", "regulatory and governmental", "technological", "managerial", "supply-chain management", and "knowledge and skills". Many studies have identified technologies as main barriers $[42,47,65,66]$ given that the transition to CE needs advanced technological infrastructure. As in the present study, Araujo Galvão [20], Govindan and Hasanagic [14], Kirchherr et al. [21], and Van Keulen and Kirchherr [23] have also addressed technology for barriers to transition to $\mathrm{CE}$. Economic investment and financial support are also critical for developing technological infrastructure. Thus, financial and economic issues create barriers [14,20]. Similarly, the present study identified Business and Business Finance as a main barrier. Government support is also required to effectively manage CE dimensions. Government regulations, incentives, and environmental standards are important to deal with CE barriers $[48,53,68]$. Therefore, many studies have addressed regulatory issues as one of the main barriers $[13,21,23]$. While the lack of adequate criteria and standards is a regulatory barrier for $\mathrm{CE}$, lack of consumer awareness and interest, and inadequate knowledge about $\mathrm{CE}$ create a cultural barrier.

$\mathrm{CE}$ requires that all levels of management adopt its principles and there is a clear management structure. Business managers need to support CE principles, so a lack of collaboration and missing information are main barriers. Thus, the managerial side has also been considered as a main barrier in the transition to CE [20]. Training is important to improve skills and knowledge in the supply chain and overcome difficulties in defining and implementing CE $[20,66]$. Because CE principles change the food supply chain, this creates issues in supply chain management regarding enhancing the network of activities, complexity, and increasing information $[41,53,65]$. Collaboration in the supply chain is necessary to deal with the lack of eco-literacy among supply chain partners along with a high degree of supply chain integration [54].

Moreover, the food supply chain requires a high level of supply chain integration among stakeholders. In the $\mathrm{CE}$ transition, coping with the growing number of suppliers, customers, and the emerging multi-stakeholder and complex nature of the food supply chain is only possible with effective digital technology tools [17]. To manage CE in the food supply chains, it is necessary to develop advanced forecasting techniques and establish systems that can cope with big data analytics [110]. In addition, the transition from the linear system to the circular system requires many legal and regulatory infrastructures. Circular design and innovations that promote sustainability and minimize waste play an important role in CE [104]. Digital technologies can provide real-time information to improve performance by ensuring efficient utilization of resources and can improve the innovation abilities of businesses for transition to CE [139]. Pagoropoulos et al. [16] has examined the role of digital technologies in adopting CE. The use of digital technologies in food supply chain management, advanced database management, and strengthened data sources, improving cooperation between stakeholders, and providing effective management of forward and reverse networks will both minimize waste and increase food safety in the food supply chain [106]. Kumar et al. [140] investigate Industry 4.0 and CE adoption barriers in the agriculture supply chain. This study aims to analyze relationship between the barriers and to prioritize them. Annosi et al. [141] have studied on how organizational and food supply chain processes are affected by the digitalization of the operations along the food supply chain. However, this study aims to reveal which Industry 4.0 tools such as big data, blockchains, and machine learning should be used to overcome specific $\mathrm{CE}$ barriers. Thus, this study proposes a variety of specific digital technologies to managers 
and decision makers in developing effective strategies for stakeholders in the food supply chain to overcome identified CE barriers.

The following section suggests various implications and future insights to overcome the barriers listed in Table 2 using digital technologies.

\section{Implications and Future Insights}

The analysis in this study has various implications for corporate culture, new process design, governmental regulations and social impact, circular design and innovations, managerial performance, and supply chain management.

Business success requires effective management of the corporate culture, including the organization's goals, strategies, structures, and shareholders. Blockchain and machine learning can help in this. Blockchain provides transparency and security of data and promotes communication in the business world. It also prevents an unsustainable, hesitant company structure by transforming a linear system into a circular one [142,143]. Maintaining trust among stakeholders in the food supply chain and ensuring reliability throughout the entire supply chain could be provided through a mechanism to monitor every transaction for every actor in the chain without a central third-party agent. The trust problem that may occur in the food supply chain can be overcome by blockchain technology. This is a digital ledger that does not depend on central servers among stakeholders. Records stored on the blockchain chain are unchangeable and trackable by all actors with the distributed ledger. This makes food supply chain data available and traceable at every step [127]. Machine learning creates a new technological infrastructure to adapt the corporate culture and knowledge to a new behavioral approach needed to transition to CE.

Increasing complexity in processes and the presence of many stakeholders in the food supply chain require the development and design of new processes using Industry 4.0 tools. Machine learning and AGV technologies deal with the uncertainty inherent in anticipating the costs of circular processes. Machine learning can be used to deal with complex logistics scenarios by investigating event correlation patterns, rule mining, and learning anomalies in event traces [144]. Machine learning provides decisions within a closed-loop structure with an uncertain and complex nature and also where the number of decisions increases due to circular and reverse operations. Leveraging machine learning techniques can uncover potential systems that contain large volumes of data and help businesses use valuable information by interfacing with legacy models [144]. Therefore, machine learning fills the gap due to the lack of a linear model by improving the capabilities of existing business models during the transition to CE [145].

Machine learning is also an effective digital technology tool to deal with the increasing number of suppliers and customers due to the multi-stakeholder nature of the food supply chain through customer and supplier tracking and analysis [146]. It also minimizes inventory costs by accurate predictions. It reduces financing costs through financial risk analysis and ensures that investments are based on more accurate estimates. It can also improve the efficiency of workflows and processes. The use of AGVs allows operations to be conducted over the system, which eliminates the short walks between assembly cycles. With the help of computer monitors, AGVs provide part numbers and assembly sequence information for each part directly to the operators [147], which increases workforce productivity.

To achieve a sustainable food supply chain, the three dimensions of sustainability (environmental, social, and economic) need to be managed simultaneously. Therefore, governmental regulations and social impact are the other significant category to overcome the barriers presented in Table 2. The transition from a linear to a circular system requires appropriate legal and regulatory infrastructure. Blockchain and big data analytics provide the necessary support to establish an appropriate legal system and improve environmental regulations by distributing transparent and secure information through governmental bodies and businesses. Big data technologies and techniques can be used to extract valid, useful relationships, patterns, and information from confidential, large-scale, complex unknown data [148]. Machine learning enables a standard system to manage CE performance 
by utilizing forecasting and analytical capabilities. Blockchain-based data processing tools can provide the transparency that is a crucial issue for taxation and incentives systems.

Circular design and innovations that support sustainability and minimize waste across the three main sustainability dimensions play an important role in CE. These innovations and circular designs can be achieved by using digital technologies, such as 3DP, nanotechnologies, and blockchains. With smart and flexible technology like 3DP, products can be made in small batches at lower cost and less waste. Thus, 3DP can cope with a complex supply chain structure. 3DP reduces waste and energy loss by decreasing unnecessary complex operations and by designing products according to the customer's requirements [108]. It thus accelerates research, development, and prototyping and decreases the technical limitations of recycling. Blockchains provide the required data integration for circular design and innovation by allowing transparent and secure information flows. Moreover, 3DP and nanotechnologies enable businesses to predict the environmental impact of circular design and processes in order to maximize the eco-efficiency of technological processes.

Managerial performance also has significant implications for overcoming CE barriers. Blockchain technology fulfills the demands of both government, businesses and consumers. Blockchain technologies can suggest innovative regulatory ideas to the government and overcome management flaws. Businesses can guarantee product quality and respond instantly to changing market demand. Blockchain technology has thus been instrumental in protecting the rights of consumers. Both the production system and consumers can obtain real-time information related to the entire process of products, which allows food supply chain operations to be conducted efficiently, transparently, and cost-effectively. For instance, big data and blockchain technologies enhance managerial functions, such as planning, organizing, staffing, directing, controlling, and decision-making. These technologies also extend the capabilities of management information systems to support information exchange and collaboration to enable a clear definition of CE dimensions. Hence, these technologies can overcome difficulties in implementing CE from managerial perspectives.

The use of digital technologies in food supply chain management ensures improved database planning and strengthened data sources, the development of cooperation, and the effective management of forward and reverse networks. Big data analytics prevents eco-literacy among supply-chain partners by estimating future parameters of ecological issues. The closed-loop food supply chain requires a high level of supply chain integration among stakeholders with the help of big data analytics at the macro level and robotics and barcodes at the operational level. Big data analytics and robotics contribute to the development of an effective framework and its adaptation by facilitating cyber-physical systems within the circular food supply chain.

\section{Conclusions}

In this study, we systematically reviewed research into CE barriers in food supply chains and proposed digital technologies to deal with them. The transition from a linear to a circular economy requires multi-perspective analyses. Thus, we first conducted a systematic literature review regarding CE barriers in food supply chains, based on 136 papers chosen with the criteria described in Section 3.1. We then identified main and sub-barriers that can hinder the implementation of $\mathrm{CE}$ in the food supply chain. The analysis offers several insights into CE barriers, especially for businesses environment. To overcome these specific barriers, we proposed various digital technologies based on the reviewed literature.

Seven main categories of barriers were identified:

- Cultural: a lack of consumer awareness and interest for cultural reasons;

- Business and business finance: insufficient access to investment and infrastructure for market design;

- Regulatory and governmental: weak regulations, policies, taxation, and incentives established by governments;

- Technological: technological limitations; 
- Managerial: limited application of business models by management;

- Supply chain management: poor corporation between suppliers because of ineffective supply chain management;

- Knowledge and skills: difficulties when defining the boundaries of CE due to the lack of knowledge and skills.

The findings indicate that the greatest barriers to adopting CE concern governmental regulations and technology issues. Specifically, the government plays a crucial role in CE implementation. Governments should therefore be aware of environmental problems and prioritize $C E$. It is also crucial that governments develop incentive policies to promote $C E$ in food supply chain. Besides, governments should also support innovation policies to provide circularity while government procurement standards should be consider recycled products [62].

Regarding technological barriers, the main problem is the lack of technological process in terms of eco-efficiency. Integration of technology and CE can overcome these barriers and improve competitiveness within an industrial context. Advanced digital technologies, i.e., Industry 4.0, can play a major role here.

Few studies have analyzed the relationship between Industry 4.0 and $\mathrm{CE}$, although these have become increasingly important for policymakers, practitioners, and scholars in recent decades. These studies mainly aim to create an innovative framework by investigating the relationships between Industry 4.0 and CE. Industry 4.0 is an important enabler of CE since digitalization helps companies achieve circularity and improve performance. Especially, Industry 4.0 applications offer managerial functions, such as planning, organizing, directing, coordinating, and controlling, while decision-making processes can be carried out effectively using big data and blockchain technologies [149]. Another promising area to improve concerns the need for a high level of food supply chain integration among stakeholders. This can be achieved through big data analytics at the macro level and robotics and barcodes at the operational level. Big data analytics and robotics can contribute to the development and implementation of an effective framework by facilitating cyber-physical systems within the circular food supply chain.

While there are many technical and regulatory challenges in implementing $\mathrm{CE}$, these obstacles can be eliminated through innovative implementation of Industry 4.0 tools in a more circular built environment. Future research may focus on further analyzing food supply chain processes to identify the enablers that can accelerate the transition to CE.

As a limitation of this study, the review includes open access articles and conference papers in English between 2010 and 2020. Thus, other languages and other types of papers were not included in this study; the relationships that it analyses are mainly a link of keywords, and the results are not empirical findings about the potential of these technologies in the food sector.

Author Contributions: Conceptualization, I.O. and C.E.-S.; methodology, C.E.-S. and I.O.; formal analysis, M.D.S.; writing-original draft preparation, I.O., C.E.-S., M.D.S. and Y.K.; writing-review and editing, Y.K., N.A. and M.R.; supervision, N.A. and Y.K. All authors have read and agreed to the published version of the manuscript.

Funding: This research received no external funding.

Institutional Review Board Statement: Not applicable.

Informed Consent Statement: Not applicable.

Data Availability Statement: Not applicable.

Conflicts of Interest: The authors declare no conflict of interest. 


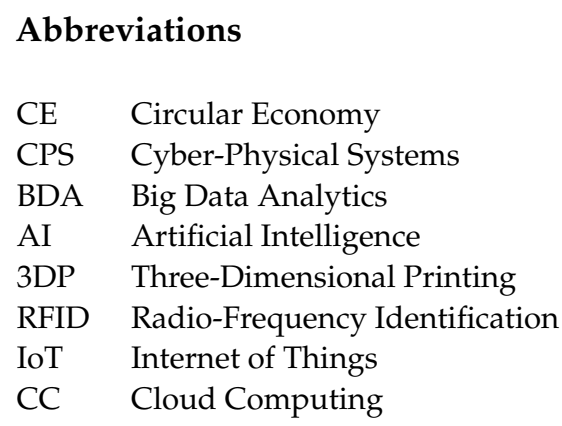

\section{References}

1. Food and Agriculture Organization of the United Nations. The State of Food and Agriculture 2019: Moving Forward on Food Loss and Waste Reduction; CCBY-NC-SA 3.0 IGO; Food and Agriculture Organization: Rome, Italy, 2019; Available online: http:/ / www.fao.org/3/ca6030en/ca6030en.pdf (accessed on 2 May 2021).

2. Ness, D. Sustainable urban infrastructure in China: Towards a Factor 10 improvement in resource productivity through integrated infrastructure systems. Int. J. Sustain. Dev. World Ecol. 2008, 15, 288-301. [CrossRef]

3. United Nations, Department of Economic and Social Affairs, Population Division. World Urbanization Prospects: The 2018 Revision (ST/ESA/SER.A/420) 2019; United Nations: New York, NY, USA; Available online: https://population.un.org/wup/Publications/ Files/WUP2018-Report.pdf (accessed on 18 February 2020).

4. ENEL. Cities of Tomorrow, Circular Cities. 2018. Available online: https://www.enel.com/content/dam/enel-com/media/ document/cities-of-tomorrow_en.pdf (accessed on 1 January 2020).

5. Corona, B.; Shen, L.; Reike, D.; Carreón, J.R.; Worrell, E. Towards Sustainable Development through the Circular Economy-A Review and Critical Assessment on Current Circularity Metrics. Resour. Conserv. Recycl. 2019, 151, 104498. [CrossRef]

6. Ellen MacArthur Foundation. Towards the Circular Economy: Economic and Business Rationale for an Accelerated Transition. Available online: https:/ / www.ellenmacarthurfoundation.org/assets/downloads/publications/Ellen-MacArthur-FoundationTowards-the-Circular-Economy-vol.1.pdf (accessed on 21 June 2020).

7. Ghisellini, P.; Cialani, C.; Ulgiati, S. A Review on Circular Economy: The Expected Transition to a Balanced Interplay of Environmental and Economic Systems. J. Clean. Prod. 2016, 114, 11-32. [CrossRef]

8. Paes, L.A.B.; Bezerra, B.S.; Deus, R.M.; Jugend, D.; Battistelle, R.A.G. Organic solid waste management in a circular economy perspective-A systematic review and SWOT analysis. J. Clean. Prod. 2019, 239, 118086. [CrossRef]

9. Zhu, J.; Fan, C.; Shi, H.; Shi, L. Efforts for a Circular Economy in China: A Comprehensive Review of Policies. J. Ind. Ecol. 2019, 23, 110-118. [CrossRef]

10. Pietzsch, N.; Ribeiro, J.L.D.; de Medeiros, J.F. Benefits, challenges and critical factors of success for Zero Waste: A systematic literature review. Waste Manag. 2017, 67, 324-353. [CrossRef]

11. Avraamidou, S.; Baratsas, S.G.; Tian, Y.; Pistikopoulos, E.N. Circular Economy-A challenge and an opportunity for Process Systems Engineering. Comput. Chem. Eng. 2020, 133, 106629. [CrossRef]

12. Farooque, M.; Zhang, A.; Liu, Y. Barriers to circular food supply chains in China. Supply Chain Manag. Int. J. 2019, 24, 677-696. [CrossRef]

13. Sharma, Y.K.; Mangla, S.K.; Patil, P.P.; Liu, S. When challenges impede the process: For circular economy-driven sustainability practices in food supply chain. Manag. Decis. 2019, 57, 995-1017. [CrossRef]

14. Govindan, K.; Hasanagic, M. A systematic review on drivers, barriers, and practices towards circular economy: A supply chain perspective. Int. J. Prod. Res. 2018, 56, 278-311. [CrossRef]

15. Bressanelli, G.; Perona, M.; Saccani, N. Challenges in supply chain redesign for the Circular Economy: A literature review and a multiple case study. Int. J. Prod. Res. 2019, 57, 7395-7422. [CrossRef]

16. Pagoropoulos, A.; Pigosso, D.C.A.; McAloone, T.C. The Emergent Role of Digital Technologies in the Circular Economy: A Review. Procedia CIRP 2017, 64, 19-24. [CrossRef]

17. Bressanelli, G.; Adrodegari, F.; Perona, M.; Saccani, N. Exploring How Usage-Focused Business Models Enable Circular Economy through Digital Technologies. Sustainability 2018, 10, 639. [CrossRef]

18. Liu, J.; Feng, Y.; Zhu, Q.; Sarkis, J. Green supply chain management and the circular economy. Int. J. Phys. Distrib. Logist. Manag. 2018, 48, 794-817. [CrossRef]

19. Seuring, S.; Gold, S. Conducting content-analysis based literature reviews in supply chain management. Supply Chain Manag. Int J. 2012, 17, 544-555. [CrossRef]

20. Galvão, G.D.A.; de Nadae, J.; Clemente, D.H.; Chinen, G.; de Carvalho, M.M. Circular Economy: Overview of Barriers. Procedia CIRP 2018, 73, 79-85. [CrossRef]

21. Kirchherr, J.; Piscicelli, L.; Bour, R.; Kostense-Smit, E.; Muller, J.; Huibrechtse-Truijens, A.; Hekkert, M. Barriers to the Circular Economy: Evidence From the European Union (EU). Ecol. Econ. 2018, 150, 264-272. [CrossRef]

22. Ghadge, A.; Kara, M.E.; Mogale, D.G.; Choudhary, S.; Dani, S. Sustainability Implementation Challenges in Food Supply Chains: A Case of UK Artisan Cheese Producers. Prod. Plan. Control. 2020, 1-16. [CrossRef] 
23. Van Keulen, M.; Kirchherr, J. The implementation of the Circular Economy: Barriers and enablers in the coffee value chain. J. Clean. Prod. 2021, 281, 125033. [CrossRef]

24. DeLorenzo, A.; Parizeau, K.; Von Massow, M. Regulating Ontario's circular economy through food waste legislation. Soc. Bus. Rev. 2019, 14, 200-216. [CrossRef]

25. Mena, C.; Adenso-Diaz, B.; Yurt, O. The causes of food waste in the supplier-retailer interface: Evidences from the UK and Spain. Resour. Conserv. Recycl. 2011, 55, 648-658. [CrossRef]

26. Parfitt, J.; Barthel, M.; Macnaughton, S. Food waste within food supply chains: Quantification and potential for change to 2050. Philos. Trans. R. Soc. B Biol. Sci. 2010, 365, 3065-3081. [CrossRef] [PubMed]

27. Pan, S.-Y.; Du, M.A.; Huang, I.-T.; Liu, I.-H.; Chang, E.-E.; Chiang, P.-C. Strategies on implementation of waste-to-energy (WTE) supply chain for circular economy system: A review. J. Clean. Prod. 2015, 108, 409-421. [CrossRef]

28. Sehnem, S.; Ndubisi, N.O.; Preschlack, D.; Bernardy, R.J.; Santos, S., Jr. Circular economy in the wine chain production: Maturity, challenges, and lessons from an emerging economy perspective. Prod. Plan. Control. 2019, 31, 1014-1034. [CrossRef]

29. Jurgilevich, A.; Birge, T.; Kentala-Lehtonen, J.; Korhonen-Kurki, K.; Pietikäinen, J.; Saikku, L.; Schösler, H. Transition towards Circular Economy in the Food System. Sustainability 2016, 8, 69. [CrossRef]

30. Russell, M.; Gianoli, A.; Grafakos, S. Getting the ball rolling: An exploration of the drivers and barriers towards the implementation of bottom-up circular economy initiatives in Amsterdam and Rotterdam. J. Environ. Plan. Manag. 2019, 63, $1903-1926$. [CrossRef]

31. Ritzén, S.; Sandström, G. Ölundh Barriers to the Circular Economy_Integration of Perspectives and Domains. Procedia CIRP 2017, 64, 7-12. [CrossRef]

32. Korhonen, J.; Honkasalo, A.; Seppälä, J. Circular Economy: The Concept and its Limitations. Ecol. Econ. 2018, 143, 37-46. [CrossRef]

33. Slorach, P.C.; Jeswani, H.K.; Cuéllar-Franca, R.; Azapagic, A. Environmental and economic implications of recovering resources from food waste in a circular economy. Sci. Total Environ. 2019, 693, 133516. [CrossRef]

34. Özbük, R.M.Y.; Coşkun, A. Factors affecting food waste at the downstream entities of the supply chain: A critical review. J. Clean. Prod. 2020, 244, 118628. [CrossRef]

35. Cakar, B.; Aydin, S.; Varank, G.; Ozcan, H.K. Assessment of environmental impact of FOOD waste in Turkey. J. Clean. Prod. 2020, 244, 118846. [CrossRef]

36. Vaneeckhaute, C.; Fazli, A. Management of ship-generated food waste and sewage on the Baltic Sea: A review. Waste Manag. 2020, 102, 12-20. [CrossRef]

37. Secondi, L. Expiry Dates, Consumer Behavior, and Food Waste: How Would Italian Consumers React If There Were No Longer "Best Before" Labels? Sustainability 2019, 11, 6821. [CrossRef]

38. Cerciello, M.; Agovino, M.; Garofalo, A. Estimating urban food waste at the local level: Are good practices in food consumption persistent? Econ. Politica 2018, 36, 863-886. [CrossRef]

39. Munesue, Y.; Masui, T. The impacts of Japanese food losses and food waste on global natural resources and greenhouse gas emissions. J. Ind. Ecol. 2019, 23, 1196-1210. [CrossRef]

40. Zhang, A.; Venkatesh, V.; Liu, Y.; Wan, M.; Qu, T.; Huisingh, D. Barriers to smart waste management for a circular economy in China. J. Clean. Prod. 2019, 240, 118198. [CrossRef]

41. Bianchini, A.; Rossi, J.; Pellegrini, M. Overcoming the Main Barriers of Circular Economy Implementation through a New Visualization Tool for Circular Business Models. Sustainablity 2019, 11, 6614. [CrossRef]

42. Fedotkina, O.; Gorbashko, E.; Vatolkina, N. Circular Economy in Russia: Drivers and Barriers for Waste Management Development. Sustainablity 2019, 11, 5837. [CrossRef]

43. Garcés-Ayerbe, C.; Rivera-Torres, P.; Suárez-Perales, I.; La Hiz, D.I.L.-D. Is It Possible to Change from a Linear to a Circular Economy? An Overview of Opportunities and Barriers for European Small and Medium-Sized Enterprise Companies. Int. J. Environ. Res. Public Heal. 2019, 16, 851. [CrossRef]

44. Tura, N.; Hanski, J.; Ahola, T.; Ståhle, M.; Piiparinen, S.; Valkokari, P. Unlocking circular business: A framework of barriers and drivers. J. Clean. Prod. 2019, 212, 90-98. [CrossRef]

45. Fux, H. What is the ideal scenario for circular economy to occur? A case study of the CircE project. Braz. J. Oper. Prod. Manag. 2019, 16, 157-165. [CrossRef]

46. Obersteg, A.; Arlati, A.; Acke, A.; Berruti, G.; Czapiewski, K.; Dabrowski, M.; Heurkens, E.; Mezei, C.; Palestino, M.F.; Varjú, V.; et al. Urban Regions Shifting to Circular Economy: Understanding Challenges for New Ways of Governance. Urban Plan. 2019, 4, 19-31. [CrossRef]

47. Hart, J.; Adams, K.; Giesekam, J.; Tingley, D.D.; Pomponi, F. Barriers and drivers in a circular economy: The case of the built environment. Procedia CIRP 2019, 80, 619-624. [CrossRef]

48. Urbinati, A.; Davide, C.; Vittorio, C. Towards a new taxonomy of circular economy business models. J. Clean. Prod. 2017, 168, 487-498. [CrossRef]

49. Berardi, P.; Betiol, L.; Dias, J. Food waste and circular economy through public policies: Portugal \& Brazil. In Proceedings of the 5th International Conference Wastes: Solutions, Treatments and Opportunities III, Lisbon, Portugal, 4-6 September 2019; CRC Press: Boca Raton, FL, USA, 2019; pp. 99-105. 
50. Yui, S.; Biltekoff, C. How Food Becomes Waste: Students as "Carriers of Practice" in the UC Davis Dining Commons. J. Hunger. Environ. Nutr. 2020, 1-22. [CrossRef]

51. Papargyropoulou, E.; Steinberger, J.K.; Wright, N.; Lozano, R.; Padfield, R.; Ujang, Z. Patterns and Causes of Food Waste in the Hospitality and Food Service Sector: Food Waste Prevention Insights from Malaysia. Sustainablility 2019, 11, 6016. [CrossRef]

52. Lemaire, A.; Limbourg, S. How can food loss and waste management achieve sustainable development goals? J. Clean. Prod. 2019, 234, 1221-1234. [CrossRef]

53. D'Agostin, A.; de Medeiros, J.F.; Vidor, G.; Zulpo, M.; Moretto, C.F. Drivers and barriers for the adoption of use-oriented product-service systems: A study with young consumers in medium and small cities. Sustain. Prod. Consum. 2020, 21, 92-103. [CrossRef]

54. Mangla, S.K.; Luthra, S.; Mishra, N.; Singh, A.; Rana, N.P.; Dora, M.; Dwivedi, Y. Barriers to effective circular supply chain management in a developing country context. Prod. Plan. Control. 2018, 29, 551-569. [CrossRef]

55. Boschini, M.; Falasconi, L.; Cicatiello, C.; Franco, S. Why the waste? A large-scale study on the causes of food waste at school canteens. J. Clean. Prod. 2020, 246, 118994. [CrossRef]

56. Filimonau, V.; Matute, J.; Kubal-Czerwińska, M.; Krzesiwo, K.; Mika, M. The determinants of consumer engagement in restaurant food waste mitigation in Poland: An exploratory study. J. Clean. Prod. 2020, 247, 119105. [CrossRef]

57. Mak, T.M.; Xiong, X.; Tsang, D.C.; Yu, I.K.; Poon, C.S. Sustainable food waste management towards circular bioeconomy: Policy review, limitations and opportunities. Bioresour. Technol. 2020, 297, 122497. [CrossRef]

58. Schiavone, S.; Pelullo, C.P.; Attena, F. Patient Evaluation of Food Waste in Three Hospitals in Southern Italy. Int. J. Environ. Res. Public Health 2019, 16, 4330. [CrossRef]

59. Abdelaal, A.H.; McKay, G.; Mackey, H.R. Food waste from a university campus in the Middle East: Drivers, composition, and resource recovery potential. Waste Manag. 2019, 98, 14-20. [CrossRef]

60. McCarthy, B.; Kapetanaki, A.B.; Wang, P. Circular agri-food approaches: Will consumers buy novel products made from vegetable waste? Rural. Soc. 2019, 28, 91-107. [CrossRef]

61. Kiefer, C.P.; González, P.D.R.; Carrillo-Hermosilla, J. Drivers and barriers of eco-innovation types for sustainable transitions: A quantitative perspective. Bus. Strat. Environ. 2019, 28, 155-172. [CrossRef]

62. Camacho-Otero, J.; Boks, C.; Pettersen, I.N. Consumption in the Circular Economy: A Literature Review. Sustainability 2018, 10, 2758. [CrossRef]

63. Loizia, P.; Neofytou, N.; Zorpas, A.A. The concept of circular economy strategy in food waste management for the optimization of energy production through anaerobic digestion. Environ. Sci. Pollut. Res. 2018, 26, 14766-14773. [CrossRef]

64. Mangialardo, A.; Micelli, E. Rethinking the Construction Industry under the Circular Economy: Principles and Case Studies. In Smart and Sustainable Planning for Cities and Regions; Springer: Cham, Switzerland, 2018; pp. 333-344. [CrossRef]

65. Rizos, V.; Behrens, A.; Van Der Gaast, W.; Hofman, E.; Ioannou, A.; Kafyeke, T.; Flamos, A.; Rinaldi, R.; Papadelis, S.; HirschnitzGarbers, M.; et al. Implementation of Circular Economy Business Models by Small and Medium-Sized Enterprises (SMEs): Barriers and Enablers. Sustainability 2016, 8, 1212. [CrossRef]

66. De Jesus, A.; Mendonça, S. Lost in Transition? Drivers and Barriers in the Eco-innovation Road to the Circular Economy. Ecol. Econ. 2018, 145, 75-89. [CrossRef]

67. Meghana, M.; Shastri, Y. Sustainable valorization of sugar industry waste: Status, opportunities, and challenges. Bioresour. Technol. 2020, 303, 122929. [CrossRef]

68. Kerdlap, P.; Low, J.S.C.; Ramakrishna, S. Zero waste manufacturing: A framework and review of technology, research, and implementation barriers for enabling a circular economy transition in Singapore. Resour. Conserv. Recycl. 2019, 151, 104438. [CrossRef]

69. Ma, Y.; Liu, Y. Turning food waste to energy and resources towards a great environmental and economic sustainability: An innovative integrated biological approach. Biotechnol. Adv. 2019, 37, 107414. [CrossRef]

70. Van der Werf, P.; Seabrook, J.A.; Gilliland, J. Food for thought: Comparing self-reported versus curbside measurements of household food wasting behavior and the predictive capacity of behavioral determinants. Waste Manag. 2020, 101, 18-27. [CrossRef] [PubMed]

71. Messner, R.; Richards, C.; Johnson, H. The "Prevention Paradox": Food waste prevention and the quandary of systemic surplus production. Agric. Hum. Values 2020, 37, 805-817. [CrossRef]

72. Bravi, L.; Francioni, B.; Murmura, F.; Savelli, E. Factors affecting household food waste among young consumers and actions to prevent it. A comparison among UK, Spain and Italy. Resour. Conserv. Recycl. 2020, 153, 104586. [CrossRef]

73. García-Herrero, L.; De Menna, F.; Vittuari, M. Food waste at school. The environmental and cost impact of a canteen meal. Waste Manag. 2019, 100, 249-258. [CrossRef]

74. Ilakovac, B.; Voca, N.; Pezo, L.; Cerjak, M. Quantification and determination of household food waste and its relation to sociodemographic characteristics in Croatia. Waste Manag. 2020, 102, 231-240. [CrossRef]

75. Kalmykova, Y.; Sadagopan, M.; Rosado, L. Circular economy-From review of theories and practices to development of implementation tools. Resour. Conserv. Recycl. 2018, 135, 190-201. [CrossRef]

76. Ghosh, P.R.; Fawcett, D.; Sharma, S.B.; Poinern, G.E.J. Progress towards Sustainable Utilisation and Management of Food Wastes in the Global Economy. Int. J. Food Sci. 2016, 2016, 1-22. [CrossRef] 
77. Irani, Z.; Sharif, A.M. Food security across the enterprise: A puzzle, problem or mess for a circular economy? J. Enterp. Inf. Manag. 2018, 31, 2-9. [CrossRef]

78. Cicatiello, C.; Franco, S. Disclosure and assessment of unrecorded food waste at retail stores. J. Retail. Consum. Serv. 2020, 52, 101932. [CrossRef]

79. Kuo, T.-C.; Smith, S. A systematic review of technologies involving eco-innovation for enterprises moving towards sustainability. J. Clean. Prod. 2018, 192, 207-220. [CrossRef]

80. Liu, Z.; Adams, M.; Walker, T.R. Are exports of recyclables from developed to developing countries waste pollution transfer or part of the global circular economy? Resour. Conserv. Recycl. 2018, 136, 22-23. [CrossRef]

81. Zeng, H.; Chen, X.; Xiao, X.; Zhou, Z. Institutional pressures, sustainable supply chain management, and circular economy capability: Empirical evidence from Chinese eco-industrial park firms. J. Clean. Prod. 2017, 155, 54-65. [CrossRef]

82. De Angelis, R.; Howard, M.; Miemczyk, J. Supply chain management and the circular economy: Towards the circular supply chain. Prod. Plan. Control. 2018, 29, 425-437. [CrossRef]

83. Salvador, R.; Barros, M.V.; da Luz, L.M.; Piekarski, C.M.; de Francisco, A.C. Circular business models: Current aspects that influence implementation and unaddressed subjects. J. Clean. Prod. 2020, 250, 119555. [CrossRef]

84. Atkins, R.; Deranek, K.; Nonet, G. Supply chain food waste reduction and the triple bottom line. Soc. Bus. 2018, 8, 121-144. [CrossRef]

85. Janssens, K.; Lambrechts, W.; Van Osch, A.; Semeijn, J. How Consumer Behavior in Daily Food Provisioning Affects Food Waste at Household Level in the Netherlands. Foods 2019, 8, 428. [CrossRef]

86. Campos, D.A.; Gómez-García, R.; Vilas-Boas, A.A.; Madureira, A.R.; Pintado, M. Management of Fruit Industrial By-Products-A Case Study on Circular Economy Approach. Molecules 2020, 25, 320. [CrossRef]

87. Walker, P.H.; Seuring, P.S.; Sarkis, J.; Klassen, P.R. Sustainable operations management: Recent trends and future directions. Int. J. Oper. Prod. Manag. 2014, 34,1-12. [CrossRef]

88. Principato, L.; Ruini, L.; Guidi, M.; Secondi, L. Adopting the circular economy approach on food loss and waste: The case of Italian pasta production. Resour. Conserv. Recycl. 2019, 144, 82-89. [CrossRef]

89. Horton, P.; Bruce, R.; Reynolds, C.; Milligan, G. Food Chain Inefficiency (FCI): Accounting Conversion Efficiencies Across Entire Food Supply Chains to Re-define Food Loss and Waste. Front. Sustain. Food Syst. 2019, 3, 79. [CrossRef]

90. Matharu, A.S.; de Melo, E.M.; Houghton, J.A. Opportunity for high value-added chemicals from food supply chain wastes. Bioresour. Technol. 2016, 215, 123-130. [CrossRef] [PubMed]

91. Wang, X.; Rodrigues, V.S.; Demir, E. Managing Your Supply Chain Pantry: Food Waste Mitigation Through Inventory Control. IEEE Eng. Manag. Rev. 2019, 47, 97-102. [CrossRef]

92. Gokarn, S.; Kuthambalayan, T.S. Analysis of challenges inhibiting the reduction of waste in food supply chain. J. Clean. Prod. 2017, 168, 595-604. [CrossRef]

93. Geissdoerfer, M.; Morioka, S.; de Carvalho, M.M.; Evans, S. Business models and supply chains for the circular economy. J. Clean. Prod. 2018, 190, 712-721. [CrossRef]

94. Irani, Z.; Sharif, A.M. Sustainable food security futures. J. Enterp. Inf. Manag. 2016, 29, 171-178. [CrossRef]

95. Tostivint, C.; De Veron, S.; Jan, O.; Lanctuit, H.; Hutton, Z.V.; Loubière, M. Measuring food waste in a dairy supply chain in Pakistan. J. Clean. Prod. 2017, 145, 221-231. [CrossRef]

96. Loke, M.K.; Leung, P. Quantifying food waste in Hawaii's food supply chain. Waste Manag. Res. 2015, 33, 1076-1083. [CrossRef]

97. Ghisellini, P.; Ulgiati, S. Circular economy transition in Italy. Achievements, perspectives and constraints. J. Clean. Prod. 2020, 243, 118360. [CrossRef]

98. Pullman, M.; Maloni, M.J.; Carter, C.R. Food for Thought: Social Versus Environmental Sustainability Practices and Performance Outcomes. J. Supply Chain Manag. 2009, 45, 38-54. [CrossRef]

99. Homrich, A.S.; Galvão, G.; Abadia, L.G.; Carvalho, M.M. The circular economy umbrella: Trends and gaps on integrating pathways. J. Clean. Prod. 2018, 175, 525-543. [CrossRef]

100. De Ferreira, A.C.; Fuso-Nerini, F. A Framework for Implementing and Tracking Circular Economy in Cities: The Case of Porto. Sustainability 2019, 11, 1813. [CrossRef]

101. Demichelis, F.; Piovano, F.; Fiore, S. Biowaste Management in Italy: Challenges and Perspectives. Sustainability 2019, $11,4213$. [CrossRef]

102. Prieto-Sandoval, V.; Jaca, C.; Santos, J.; Baumgartner, R.J.; Ormazabal, M. Key strategies, resources, and capabilities for implementing circular economy in industrial small and medium enterprises. Corp. Soc. Responsib. Environ. Manag. 2019, 26, 1473-1484. [CrossRef]

103. Vlajic, J.V.; Mijailović, R.; Bogdanova, M. Creating loops with value recovery: Empirical study of fresh food supply chains. Prod. Plan. Control. 2018, 29, 522-538. [CrossRef]

104. Ingemarsdotter, E.; Jamsin, E.; Balkenende, R. Opportunities and challenges in IoT-enabled circular business model implementation-A case study. Resour. Conserv. Recycl. 2020, 162, 105047. [CrossRef]

105. Dev, N.K.; Shankar, R.; Qaiser, F.H. Industry 4.0 and circular economy: Operational excellence for sustainable reverse supply chain performance. Resour. Conserv. Recycl. 2020, 153, 104583. [CrossRef]

106. Vanderroost, M.; Ragaert, P.; Verwaeren, J.; De Meulenaer, B.; De Baets, B.; Devlieghere, F. The digitization of a food package's life cycle: Existing and emerging computer systems in the logistics and post-logistics phase. Comput. Ind. 2017, 87, 15-30. [CrossRef] 
107. Hofmann, E.; Rüsch, M. Industry 4.0 and the current status as well as future prospects on logistics. Comput. Ind. 2017, 89, 23-34. [CrossRef]

108. Haji, M.; Kerbache, L.; Muhammad, M.; Al-Ansari, T. Roles of Technology in Improving Perishable Food Supply Chains. Logistics 2020, 4, 33. [CrossRef]

109. Hu, F.; Li, L.I.; Liu, Y.; Yan, D. Enhancement of agility in small-lot production environment using 3D printer, industrial robot and machine vision. Int. J. Simul. Syst. Sci. Technol. 2016, 17, 32-37.

110. Yu, C.; Xu, X.; Lu, Y. Computer-Integrated Manufacturing, Cyber-Physical Systems and Cloud Manufacturing-Concepts and relationships. Manuf. Lett. 2015, 6, 5-9. [CrossRef]

111. De Sousa Jabbour, A.B.L.; Jabbour, C.J.C.; Godinho-Filho, M.; Roubaud, D. Industry 4.0 and the circular economy: A proposed research agenda and original roadmap for sustainable operations. Ann. Oper. Res. 2018, 270, 273-286. [CrossRef]

112. Frank, A.G.; Dalenogare, L.G.; Ayala, N.F. Industry 4.0 technologies: Implementation patterns in manufacturing companies. Int. J. Prod. Econ. 2019, 210, 15-26. [CrossRef]

113. Rocca, R.; Rosa, P.; Sassanelli, C.; Fumagalli, L.; Terzi, S. Industry 4.0 solutions supporting Circular Economy. In Proceedings of the 2020 IEEE International Conference on Engineering, Technology and Innovation (ICE/ITMC), Cardiff, UK, 15-17 June 2020; pp. 1-8.

114. Alfian, G.; Syafrudin, M.; Farooq, U.; Ma'arif, M.R.; Syaekhoni, M.A.; Fitriyani, N.L.; Rhee, J. Improving efficiency of RFID-based traceability system for perishable food by utilizing IoT sensors and machine learning model. Food Control 2020, 110, 107016. [CrossRef]

115. Costa, C.; Antonucci, F.; Pallottino, F.; Aguzzi, J.; Sarriá, D.; Menesatti, P. A Review on Agri-food Supply Chain Traceability by Means of RFID Technology. Food Bioprocess Technol. 2013, 6, 353-366. [CrossRef]

116. Accorsi, R.; Bortolini, M.; Baruffaldi, G.; Pilati, F.; Ferrari, E. Internet-of-things Paradigm in Food Supply Chains Control and Management. Procedia Manuf. 2017, 11, 889-895. [CrossRef]

117. Ben-Daya, M.; Hassini, E.; Bahroun, Z.; Banimfreg, B.H. The role of internet of things in food supply chain quality management: A review. Qual. Manag. J. 2021, 28, 17-40. [CrossRef]

118. Yadav, S.; Luthra, S.; Garg, D. Internet of things (IoT) based coordination system in Agri-food supply chain: Development of an efficient framework using DEMATEL-ISM. Oper. Manag. Res. 2020, 1-27. [CrossRef]

119. Singh, A.; Mishra, N.; Ali, S.I.; Shukla, N.; Shankar, R. Cloud computing technology: Reducing carbon footprint in beef supply chain. Int. J. Prod. Econ. 2015, 164, 462-471. [CrossRef]

120. Singh, A.; Kumari, S.; Malekpoor, H.; Mishra, N. Big data cloud computing framework for low carbon supplier selection in the beef supply chain. J. Clean. Prod. 2018, 202, 139-149. [CrossRef]

121. Duan, J.; Zhang, C.; Gong, Y.; Brown, S.; Li, Z. A Content-Analysis Based Literature Review in Blockchain Adoption within Food Supply Chain. Int. J. Environ. Res. Public Health 2020, 17, 1784. [CrossRef]

122. Rana, R.L.; Tricase, C.; De Cesare, L. Blockchain technology for a sustainable agri-food supply chain. Br. Food J. 2021. [CrossRef]

123. Khan, S.A.R.; Yu, Z.; Sarwat, S.; Godil, D.I.; Amin, S.; Shujaat, S. The role of block chain technology in circular economy practices to improve organisational performance. Int. J. Logist. Res. Appl. 2021, 1-18. [CrossRef]

124. Köhler, S.; Pizzol, M. Technology assessment of blockchain-based technologies in the food supply chain. J. Clean. Prod. 2020, 269, 122193. [CrossRef]

125. Chen, S.; Liu, X.; Yan, J.; Hu, G.; Shi, Y. Processes, benefits, and challenges for adoption of blockchain technologies in food supply chains: A thematic analysis. Inf. Syst. e-Bus. Manag. 2020, 1-27. [CrossRef]

126. Casino, F.; Kanakaris, V.; Dasaklis, K.T.; Moschuris, S.; Stachtiaris, S.; Pagoni, M.; Rachaniotis, P.N. Block-chain-based food supply chain traceability: A case study in the dairy sector. Int. J. Prod. Res. 2020. [CrossRef]

127. Caro, M.P.; Ali, M.S.; Vecchio, M.; Giaffreda, R. Blockchain-based traceability in Agri-Food supply chain management: A practical implementation. In 2018 IoT Vertical and Topical Summit on Agriculture-Tuscany (IOT Tuscany); Institute of Electrical and Electronics Engineers (IEEE): New York, NY, USA, 2018; pp. 1-4.

128. Sharma, R.; Kamble, S.S.; Gunasekaran, A.; Kumar, V.; Kumar, A. A systematic literature review on machine learning applications for sustainable agriculture supply chain performance. Comput. Oper. Res. 2020, 119, 104926. [CrossRef]

129. Abdella, G.M.; Kucukvar, M.; Onat, N.C.; Al-Yafay, H.M.; Bulak, M.E. Sustainability assessment and modeling based on supervised machine learning techniques: The case for food consumption. J. Clean. Prod. 2020, 251, 119661. [CrossRef]

130. Olan, F.; Liu, S.; Suklan, J.; Jayawickrama, U.; Arakpogun, E. The role of Artificial Intelligence networks in sustainable supply chain finance for food and drink industry. Int. J. Prod. Res. 2021. [CrossRef]

131. Jung, J.; Maeda, M.; Chang, A.; Bhandari, M.; Ashapure, A.; Landivar-Bowles, J. The potential of remote sensing and artificial intelligence as tools to improve the resilience of agriculture production systems. Curr. Opin. Biotechnol. 2021, 70, 15-22. [CrossRef] [PubMed]

132. Smetana, S.; Aganovic, K.; Heinz, V. Food Supply Chains as Cyber-Physical Systems: A Path for More Sustainable Personalized Nutrition. Food Eng. Rev. 2021, 13, 92-103. [CrossRef]

133. Liu, P.; Long, Y.; Song, H.-C.; He, Y.-D. Investment decision and coordination of green agri-food supply chain considering information service based on blockchain and big data. J. Clean. Prod. 2020, 277, 123646. [CrossRef]

134. Kazancoglu, Y.; Pala, M.O.; Sezer, M.D.; Luthra, S.; Kumar, A. Drivers of implementing Big Data Analytics in food supply chains for transition to a circular economy and sustainable operations management. J. Enterp. Inf. Manag. 2021. [CrossRef] 
135. Misra, N.N.; Dixit, Y.; Al-Mallahi, A.; Bhullar, M.S.; Upadhyay, R.; Martynenko, A. IoT, big data and artificial intelligence in agriculture and food industry. IEEE Internet Things J. 2020, 1. [CrossRef]

136. Sun, J.; Peng, Z.; Yan, L.; Fuh, J.Y.H.; Hong, G.S. 3D food printing-An innovative way of mass customization in food fabrication. Int. J. Bioprinting 2015, 1, 27-38. [CrossRef]

137. Halassi, S.; Semeijn, J.; Kiratli, N. From consumer to prosumer: A supply chain revolution in 3D printing. Int. J. Phys. Distrib. Logist. Manag. 2019, 49, 200-216. [CrossRef]

138. Duong, L.N.; Al-Fadhli, M.; Jagtap, S.; Bader, F.; Martindale, W.; Swainson, M.; Paoli, A. A review of robotics and autonomous systems in the food industry: From the supply chains perspective. Trends Food Sci. Technol. 2020, 106, 355-364. [CrossRef]

139. Kittipanya-Ngam, P.; Tan, K.H. A framework for food supply chain digitalization: Lessons from Thailand. Prod. Plan. Control. 2019, 31, 158-172. [CrossRef]

140. Kumar, S.; Raut, R.D.; Nayal, K.; Kraus, S.; Yadav, V.S.; Narkhede, B.E. To identify industry 4.0 and circular economy adoption barriers in the agriculture supply chain by using ISM-ANP. J. Clean. Prod. 2021, 293, 126023. [CrossRef]

141. Annosi, M.C.; Brunetta, F.; Bimbo, F.; Kostoula, M. Digitalization within food supply chains to prevent food waste. Drivers, barriers and collaboration practices. Ind. Mark. Manag. 2021, 93, 208-220. [CrossRef]

142. Davenport, M.L.; Qi, D.; Roe, B.E. Food-related routines, product characteristics, and household food waste in the United States: A refrigerator-based pilot study. Resour. Conserv. Recycl. 2019, 150, 1-16. [CrossRef]

143. Giboreau, A.; Schwartz, C.; Morizet, D.; Meiselman, H.L. Measuring Food Waste and Consumption by Children Using Photography. Nutrients 2019, 11, 2410. [CrossRef]

144. Konovalenko, I.; Ludwig, A. Event processing in supply chain management-The status quo and research outlook. Comput. Ind. 2019, 105, 229-249. [CrossRef]

145. Jaeger, B.; Upadhyay, A. Understanding barriers to circular economy: Cases from the manufacturing industry. J. Enterp. Inf. Manag. 2020, 33, 729-745. [CrossRef]

146. Kok, L.; Wurpel, G.; Ten Wolde, A. Unleashing the Power of the Circular Economy. 2013. Available online: http:/ /www.imsa.nl/ uploads/Unleashing_the_Power_of_the_Circular_Economy-Circle_Economy.pdf (accessed on 15 February 2020).

147. Emde, S.; Gendreau, M. Scheduling in-house transport vehicles to feed parts to automotive assembly lines. Eur. J. Oper. Res. 2017, 260, 255-267. [CrossRef]

148. Chalmeta, R.; Santos-Deleón, N.J. Sustainable Supply Chain in the Era of Industry 4.0 and Big Data: A Systematic Analysis of Literature and Research. Sustainability 2020, 12, 4108. [CrossRef]

149. Rosa, P.; Sassanelli, C.; Urbinati, A.; Chiaroni, D.; Terzi, S. Assessing relations between Circular Economy and Industry 4.0: A systematic literature review. Int. J. Prod. Res. 2019, 58, 1662-1687. [CrossRef] 